\title{
Velocity anisotropy of Upper Jurassic organic-rich shales, Norwegian Continental Shelf
}

\author{
Mohammad Koochak Zadeh ${ }^{1}$, Nazmul Haque Mondol ${ }^{2}$, and Jens Jahren ${ }^{1}$
}

\begin{abstract}
This study investigates the seismic velocity anisotropy of two organic-rich shales from the Norwegian Continental Shelf. The tested organic-rich shale samples were from the Upper Jurassic Draupne and Hekkingen formations collected from two wells (16/ 8-3S and 7125/1-1) drilled in the central North Sea and western Barents Sea, respectively. The two tested shales are different in organic matter richness and thermal maturation, and they have experienced different burial histories. The shale core plugs were tested in a triaxial cell under controlled pore pressure. Seismic velocities $\left(V_{\mathrm{P}}\right.$ and $\left.V_{\mathrm{S}}\right)$ were measured along different orientations with respect to layering to identify the complete tensor of the rock elastic moduli, and to investigate the velocity anisotropy as a function of increasing effective stress. The measured velocity values exhibit strong anisotropy for the two tested organic-rich
\end{abstract}

\begin{abstract}
shales. The anisotropy for both shales is strongest for $V_{\mathrm{S}}$. Seismic velocities follow an increasing trend as the effective stress increases. The anisotropy decreases somewhat with increasing consolidation, probably due to the closing of preexisting fractures and microcracks. The reduction of anisotropy is more evident for the P-wave because it decreases from 0.32 to 0.25 for the Draupne sample and from 0.28 to 0.24 for the Hekkingen sample when the vertical effective stress increases from 26 to $50 \mathrm{MPa}$. In general, the Hekkingen sample indicates slightly higher velocity values than the Draupne sample due to more compaction and lower porosity. In spite of major differences between the two shale formations in terms of organic matter content, maturity and burial history, they indicate almost the same degree of velocity anisotropy. The outcomes of this study can contribute to better imaging of organic-rich Draupne and Hekkingen shales by constraining the rock-physics properties.
\end{abstract}

\section{INTRODUCTION}

Organic-rich shales play crucial roles in petroleum systems. They are the main type of source rocks to generate hydrocarbons, and in parallel they act as seal/cap rock in many petroleum systems. Although the fine-grained mudstones and shales comprise $70 \%-$ $80 \%$ of the sediments and sedimentary rocks worldwide, only a few shale horizons can be found in sedimentary basins that are rich in organic matter. Eustatic sea-level rise in a global scale during the Late Jurassic time resulted in a widespread deposition of organicrich shales in different sedimentary basins across the world (Haq et al., 1987; Klemme and Ulmishek, 1991; Hallam, 2001). The high potentiality of Upper Jurassic organic-rich shales as source rocks is documented in several prosperous petroleum provinces, such as the Gulf of Mexico, North Sea, Middle East, Eastern Africa, Western
Siberia, Middle Asia, and Cooper Basin in Australia (Klemme and Ulmishek, 1991). In this study, two Upper Jurassic organic-rich shales located in the Norwegian Continental Shelf (NCS) are selected to investigate their velocity anisotropy. One core is taken from the Draupne Formation in well 16/8-3S located in the central North Sea, and the other core is taken from the Hekkingen Formation in well 7125/1-1 located in the Norwegian Barents Sea (Figure 1). Upper Jurassic Draupne and Hekkingen formations are the two important organic-rich shales in the NCS, which have been source rocks to most of the hydrocarbon fields in the central North Sea and the Norwegian Barents Sea. These shales also serve as seal/ cap rocks for their underlying sandstone reservoirs. Moreover, recent advances in directional drilling and hydraulic fracturing could bring these organic-rich shales as future unconventional resources in the NCS.

\footnotetext{
Manuscript received by the Editor 18 January 2016; revised manuscript received 27 August 2016; published online 15 February 2017.

${ }^{1}$ University of Oslo, Department of Geosciences, Oslo, Norway. E-mail: m.k.zadeh@geo.uio.no; jens.jahren@geo.uio.no.

${ }^{2}$ University of Oslo, Department of Geosciences, Oslo, Norway and Norwegian Geotechnical Institute, Oslo, Norway. E-mail: azmul.mondol@ngi.no.

(C) 2017 Society of Exploration Geophysicists. All rights reserved.
} 
Most organic-rich shales show anisotropy in their acoustic, electric, and hydraulic properties (Thomsen, 1986; Vernik and Nur, 1992; Vernik and Landis, 1996; Hornby, 1998; Sondergeld et al., 2000). The anisotropy is due to variation in intrinsic properties of clay particles, total organic carbon (TOC), their thermal maturation and tendency of clay minerals to align as plates (Jones and Nur, 1984; Vernik and Nur, 1992; Mondol et al., 2010). Due to the significant importance of organic-rich shales in conventional and unconventional hydrocarbon resources, a better understanding of the velocity anisotropy is necessary to constrain seismic velocity analysis (Alkhalifah, 1996), interpretation and inversion of azimuthally varying nonhyperbolic reflection moveout in seismic signature analysis (Pech et al., 2003; Pech and Tsvankin, 2004; Grechka and Pech, 2006), amplitude variation with offset analysis (Wright, 1987), interpretation of sonic log data (Vernik and Nur, 1992), and imaging of subsurface structures (Meadows and Abriel, 1994). Moreover, knowledge of anisotropy of the hydraulic and acoustic properties of different shales may contribute to improved understanding of seal quality because the presence of fractures and microcracks in shales are important parameters to influence velocity anisotropy and pose a potential risk of cap rock failure to trap reservoir fluids.

Despite the importance of anisotropy parameters in organic-rich shales, they have not been studied extensively because shales are rarely cored in boreholes. A few laboratory studies have investigated the elastic anisotropy of organic-rich shales acquired from different geologic settings (Jones and Wang, 1981; Vernik and Nur, 1992; Vernik and Landis, 1996; Vernik and Liu, 1997; Hornby, 1998; Sayers, 1999; Wang, 2002; Sondergeld and Rai, 2011). By testing 17 brine-saturated shales, Wang (2002) finds that porosity is an important factor controlling velocity anisotropy in this rock type such that decreasing porosity increases anisotropy. Decreasing porosity as a result of mechanical and chemical compaction processes causes more lamination of shales, and the increased preferential orientation of the clay platelets leads to increasing anisotropy. In general, anisotropy in shales is highly affected by stress-induced fractures and microcracks with preferred alignment (Vernik and Nur, 1992; Dewhurst and Siggins, 2006; Sarout and Guéguen, 2008a; Dewhurst et al., 2011; Sondergeld and Rai, 2011). In addition, the increasing kerogen content embedded in organic-rich shales and thermal maturation of organic matter are recognized as contributing parameters to increase the velocity anisotropy (Vernik and Nur, 1992; Vernik and Landis, 1996; Vernik and Liu, 1997; Sondergeld et al., 2000).

Most previous anisotropy studies of organic-rich shales were performed under dry or unsaturated conditions. A few experimental studies have tested organic-rich shales under brine-saturated condition, but most of these tests were performed in undrained conditions. Testing shales in an undrained brine-saturated condition may result in pressure buildup of the pore fluid filling the preexisting fractures and microcracks in the tested samples unless the pore pressure is controlled during the tests as was done in a few recent studies (e.g., Dewhurst and Siggins, 2006; Delle Piane et al., 2011; Dewhurst et al., 2011; Sarout et al., 2014, 2015). Therefore, the drained brine-saturated condition with full control on pore pressure better emulates the natural condition and is the most favorable one to assess rock physical properties of the tested samples in a condition close to natural circumstances. Because shales have very low permeability, testing and measurement of elastic properties in drained condition under controlled pore pressure is time consuming and requires an extremely slow rate of strain test protocol to avoid pressure buildup as a function of increasing effective stresses.

In this study, the velocity anisotropy of two well-characterized organic-rich shales (Kimmeridge equivalent Draupne and Hekkingen shales) is investigated as a function of increasing effective stress using a triaxial cell that has the capability to control the pore pressure under a drained condition. The tested shale samples were deposited at the same geologic time under almost the same depositional conditions and show almost similar mineralogical composition, although they are different in terms of kerogen content, thermal maturity, total porosity, and even burial history. The Draupne Formation is progressively buried during its deposition in the central North Sea, and at present it is at maximum burial depth, whereas the Hekkingen Formation in the western Barents Sea has been uplifted (approximately $1.3 \mathrm{~km}$ ) compared with its maximum burial depth (Faleide et al., 1984; Henriksen et al., 2011). The measurement of the acoustic velocity along different orientations of the samples under in situ stress and pore pressure conditions will enhance our understanding of velocity anisotropy and help to find which parameters are most important to govern anisotropy. Moreover, the relationship between rock physical properties such as acoustic velocity and total porosity can contribute significantly to better the understanding of organic-rich shales.

\section{GEOLOGIC FRAMEWORK}

The well 16/8-3S is in the Ling Depression located in the central North Sea (Figure 1). This well penetrates the Upper Jurassic Draupne Formation at a depth of $2570 \mathrm{~m}$ reference to the rotary kelly bushing (RKB). The thickness of the Draupne Formation is $86 \mathrm{~m}$ at the well location. The Draupne Formation is a black shale deposited in a marine environment with restricted bottom circulation and often with anaerobic conditions (Harms et al., 1981). The formation is widely deposited in the East Shetland Platform, the Viking Graben, the Ling Depression, and over the Horda Platform. It is a rich source rock in the North Sea and also a good seal for Middle Jurassic sandstone reservoirs in the area. Equivalent formations are the Kimmeridge Clay Formation on the British side of the North Sea and the Spekk Formation in the Norwegian Sea (Vollset and Doré, 1984). Figure 2 shows the stratigraphic column of sediments deposited in the area. The Draupne Formation is bounded by the Cretaceous shale (Cromer Knoll Group) at the top and Triassic sandstone (Hegre Group) at the base. Early to mid-Jurassic regional uplift resulted in the erosion or nondeposition of Lower Jurassic strata over the study area (Cutts, 1991; Underhill and Partington, 1993). Therefore, the Upper Jurassic Draupne shales rest unconformably on Triassic sandstones due to this episode of erosion. However, no major exhumation has been reported in this area since the Late Jurassic, and consequently, the Draupne Formation sediments are buried at their maximum burial depth presently (Faleide et al., 2002).

The well 7125/1-1 is in the western Barents Sea located near the Nysleppen Fault Complex between the Hammerfest and Nordkapp Basins (Figure 1). The well penetrates the Hekkingen Formation at a depth of $1344 \mathrm{~m} \mathrm{RKB}$, and the thickness of the formation is $55 \mathrm{~m}$ at the well location. The Hekkingen Formation consists of brownish-gray to very dark gray shale and claystone with occasional thin beds of limestone, dolomite, siltstone, and sandstone (Dalland et al., 1988). The Draupne and Hekkingen formations are characterized by 
high gamma rays due to the high organic matter content. The Hekkingen Formation is bounded by fine-grained sediments of the Knurr Formation at the top and sandstones of the Stø Formation at the base (Figure 2). The sediments deposited in the Barents Sea region are affected by several phases of uplift and net erosion because of opening stages of the Atlantic and Arctic oceans and also glacial erosion during the Plio-Pleistocene period (Faleide et al., 1993; Dore and Lundin, 1996; Henriksen et al., 2011). The amount of exhumation is varied between 400 and $3000 \mathrm{~m}$ in different parts of the greater Barents Sea (Ohm et al., 2008; Henriksen et al., 2011; Baig et al., 2016). Henriksen et al. (2011) and Baig et al. (2016) estimate $1300 \mathrm{~m}$ of exhumation for the Jurassic sediments at well 7125/1-1.

\section{MATERIALS AND METHODS}

\section{Samples preparation and characterization}

From each of the cores drilled out of the Upper Jurassic Draupne and Hekkingen formations, two cylindrical core plugs (one perpendicular to layering and another at $45^{\circ}$ to the layering with less than $\pm 1^{\circ}$ of error) with dimensions of approximately $25 \mathrm{~mm}$ in diameter and approximately $20 \mathrm{~mm}$ in height were prepared (Figure 3a). The Draupne and Hekkingen core plugs were picked from measured depths of 2582.25 and $1365.11 \mathrm{~m} \mathrm{RKB}$, respectively. Bulk and clay mineral analyses were carried out by preparing randomly oriented powder and oriented clay fraction $(<2 \mu \mathrm{m})$, respectively, for X-ray diffraction (XRD) analysis with the use

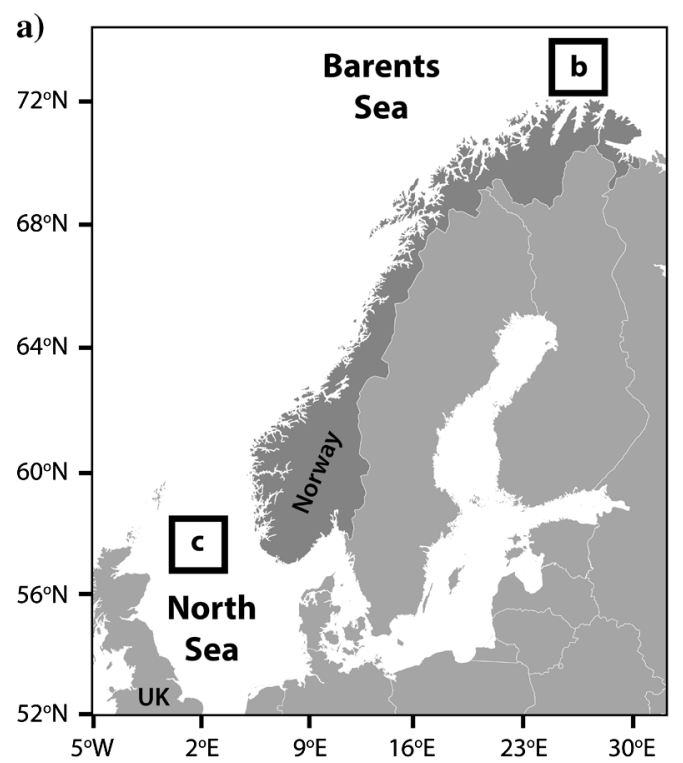

b)

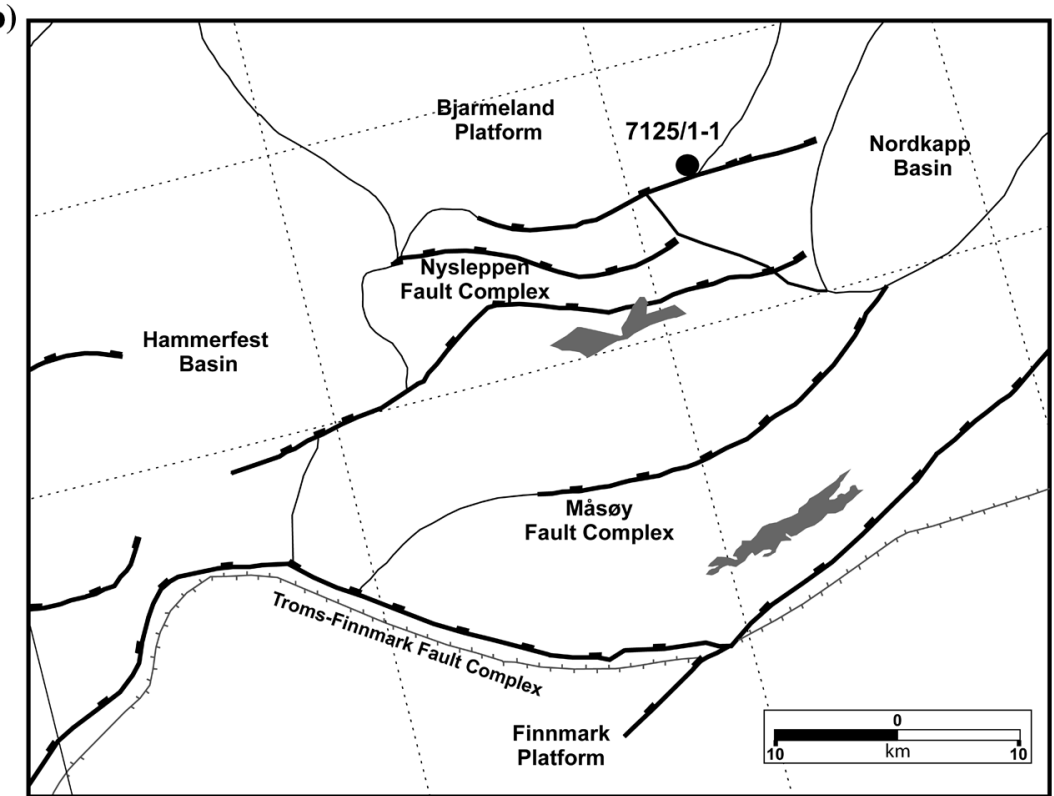

c)

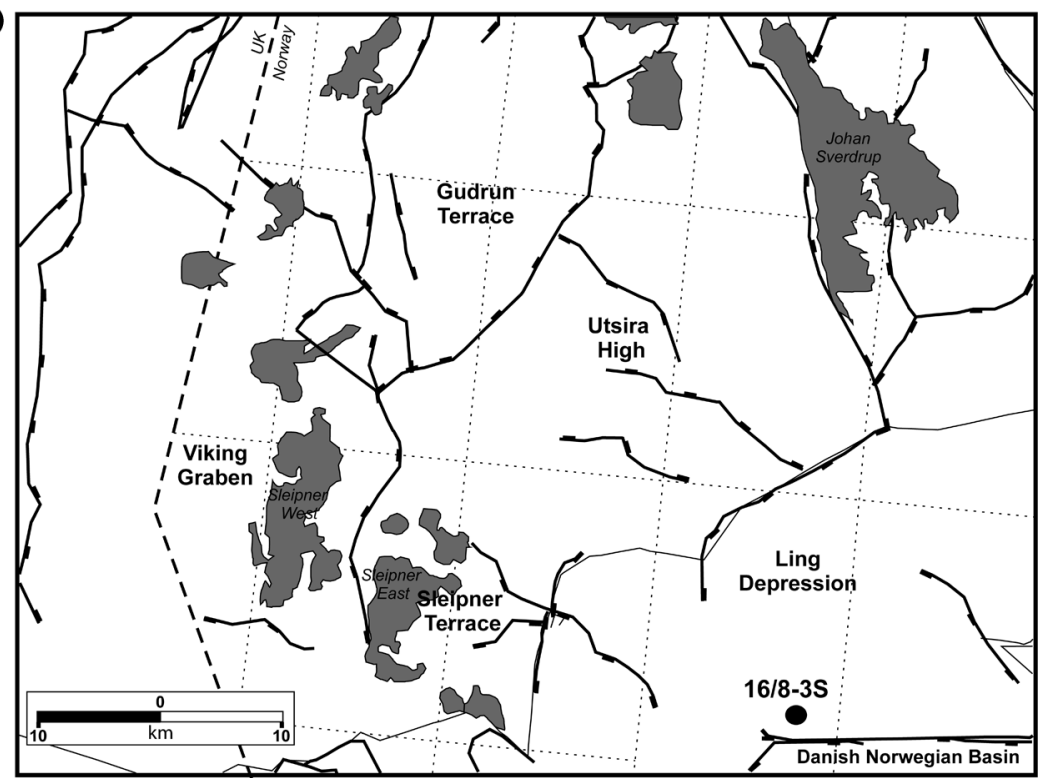

Figure 1. The location map and structural framework in location of wells 16/8-3S and 7125/1-1, where the organic-rich shale cores tested in this study are taken from. 
of a Bruker D8 ADVANCE machine. Oriented clay aggregates were prepared in the forms of $\mathrm{Mg}$-saturated air-dried samples that were subsequently treated with ethylene glycol, heating to $400^{\circ} \mathrm{C}$ and $550^{\circ} \mathrm{C}$ as suggested by Poppe et al. (2001). The bulk and clay mineralogical composition related to each sample is listed in Table 1.

A helium pycnometer was used to measure the grain density of the crushed and dried samples. The effective grain density $\rho_{g}$ was 2.5 and $2.3 \mathrm{~g} / \mathrm{cm}^{3}$ for the Draupne and Hekkingen samples, respectively. The bulk density of each core plug could be calculated according to its measured weight and volume. The bulk and grain density values were applied to calculate the total porosity of the samples at ambient condition based on the following equation:

$$
\phi_{0}=\frac{m / \rho_{b}-m / \rho_{g}}{m / \rho_{b}},
$$

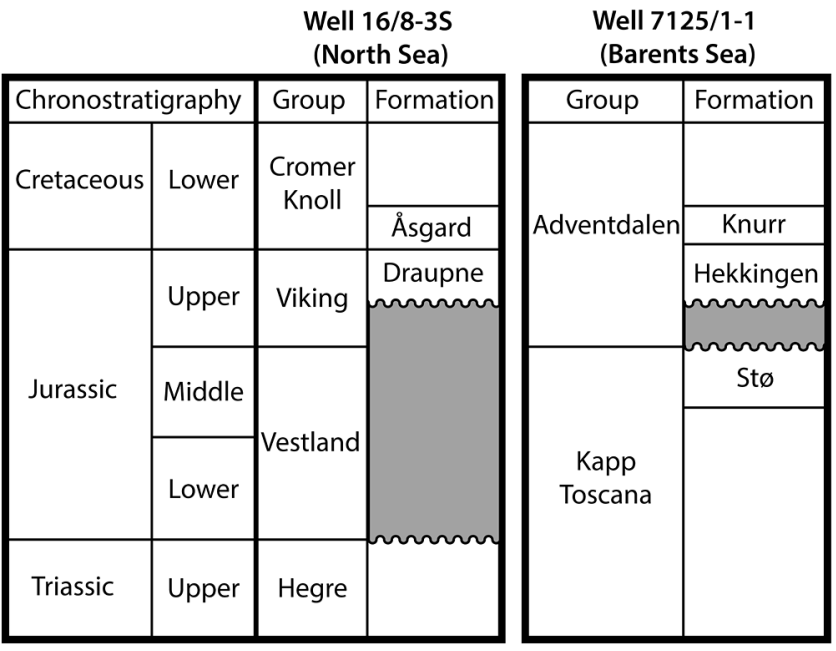

Figure 2. Generalized lithostratigraphic column for the locations of the wells 16/8-3S and 7125/1-1 situated in the central North Sea and the Norwegian Barents Sea regions, modified from Dalland et al. (1988) and Gabrielsen et al. (1990), respectively.

Table 1. Bulk and clay mineralogical composition of the tested Draupne and Hekkingen shale core plugs.

Draupne

\begin{tabular}{lccccccc}
\hline $\begin{array}{l}\text { Bulk mineralogy } \\
(\%)\end{array}$ & \multicolumn{2}{c}{$\begin{array}{c}\text { Clay mineralogy } \\
(\%)\end{array}$} & \multicolumn{2}{c}{$\begin{array}{c}\text { Bulk mineralogy } \\
(\%)\end{array}$} & \multicolumn{2}{c}{$\begin{array}{c}\text { Clay mineralogy } \\
(\%)\end{array}$} \\
\hline Quartz & 22.40 & Kaolinite & 62.1 & Quartz & 24.20 & Kaolinite & 47 \\
Microcline & 17.8 & Smectite & 18 & Microcline & 2.9 & Smectite & 20.8 \\
Albite & - & Chlorite & 0.7 & Albite & 1.7 & Chlorite & - \\
Pyrite & 7.7 & Mica/Illite & 19.3 & Pyrite & 5.6 & Mica/Illite & 32 \\
Calcite & 0.7 & - & - & Calcite & 2.8 & - & - \\
Dolomite & 1.2 & - & - & Dolomite & 1.7 & - & - \\
Total clay & 50.7 & - & - & Total clay & 61 & - & - \\
\hline
\end{tabular}

where $\phi_{0}$ is the initial total porosity at ambient condition. Also, $m$ and $\rho_{b}$ are the mass and bulk density of the core plug, respectively. The tested core plugs were dried after the test in an oven at $60^{\circ} \mathrm{C}$ to calculate the water content of each specimen. The water content of the tested Draupne and Hekkingen shale samples was measured at approximately $8 \%$ and $4 \%$, respectively. A summary of physical properties for each shale sample is given in Table 2 .

The TOC content of the Draupne shale was obtained from a pulverized sample analyzed on a LECO SC-632 instrument. Also, the hydrocarbon generation potential and thermal maturity of the Draupne shale were determined by Rock-Eval pyrolysis of a crushed pulverized sample. Hydrogen index (HI) was calculated from the pyrolysis data by dividing the amount of organic matter pyrolized in the rock over the TOC content. HI can provide a quantitative measure on the maturation level of the organic matter embedded in the rocks. For the Hekkingen sample, the geochemical information was adopted from the Norwegian Petroleum Directorates (NPD) fact pages (NPD, 2015) which provided Rock-Eval pyrolysis data from drilled cuttings. The geochemical information related to both tested samples is also presented in Table 2 .

For permeability estimation, constant head permeability tests were carried out by applying a constant gradient between the top and bottom of the samples (Skurtveit et al., 2015). Permeability was calculated using a brine density of $1.025 \mathrm{~g} / \mathrm{cm}^{3}$ and viscosity of 1.085 centipoise (1085 Pa.s). The measured permeability for tested core plugs perpendicular to the layering is extremely low for both samples (approximately $1-2 \times 10^{-10} \mathrm{mD}$ ).

\section{Experimental setup and loading protocol}

The prepared core plugs were tested in a triaxial cell at Norwegian Geotechnical Institute (NGI) laboratory. The triaxial apparatus allows controlling pore pressure, confining pressure, and deviatoric stress on cylindrical samples independently with operational upper limits of 64,64, and $300 \mathrm{MPa}$, respectively. Figure $3 \mathrm{~b}$ shows a schematic sketch of the triaxial cell. The specimen is mounted in a sealed flexible membrane preventing contact between the confining fluid (oil in this case) and the specimen. The sample deformation in the axial direction was accurately measured by two linearly variable displacement transducers (LVDTs). The radial displacement of the sample was also measured by one LVDT sensor measuring the diameter of the specimen. For the specimens drilled $45^{\circ}$ to the layering, the radial LVDT was placed such that to measure the diameter of the specimens in the same orientation as the strike of the layering. At each stress level, the vertical (or axial) strain was calculated by dividing the measured axial displacement over the initial height of the specimen. The horizontal (or radial) strain was computed by dividing the changes in the diameter of the specimen over the initial diameter of the specimen.

The velocity measurements were based on the pulse transmission technique between a transmitting and a receiving transducer (Birch, 1960) using a functional resonant frequency of $500 \mathrm{kHz}$. The triaxial cell was equipped with acousticmeasurement transducers situated at the top and bottom of the specimen to measure the traveltime of the P- and S-waves (blue and red waveforms in 
Figure 4 , respectively) passing through the specimen to calculate the corresponding velocities. In addition, radial transducers were mounted orthogonally on the membrane to measure the radial Pand S-wave velocities along the horizontal direction of the core sample. The traveltimes associated with the radial $\mathrm{P}$ - and $\mathrm{S}$-waves were picked on a single waveform (the green waveforms in Figure 4). Figure $3 \mathrm{a}$ shows a schematic diagram of the transducers configuration around the sample. The transit times related to the first arrivals of the $\mathrm{P}$ - and $\mathrm{S}$-waves were picked as indicated by the black lines in Figure 4 . The reference measurements for the axial velocity were taken under $20 \mathrm{MPa}$ applied vertical stress with the transducers in contact with each other in a "no-sample" or "head-to-head" configuration. To find the reference measurement for the radial velocity, an isotropic dummy specimen with known values of velocities was used to find the time corresponding to the no-sample configuration.

By having the height or diameter of the specimen at a given effective stress and the time difference between the reference time and the time of first arrival, one can easily calculate the velocity of the sample at the corresponding effective stress level. The maximum absolute error resulting from errors in picking the first arrival transit times is considered to be the same as the sampling rate of recorded waveforms equivalent to $\pm 0.1 \mu$ s for P- and S-waves. The relative errors could be calculated as explained by Hornby (1998) and Mondol et al. (2008). Assuming the precision of the LVDT sample length measurement as $0.25 \%$ (equivalent to $0.05 \mathrm{~mm}$ for a typical sample length of $20 \mathrm{~mm}$ ) gives maximum relative errors of $\pm 5 \%$ and $\pm 1.5 \%$ to calculate the P-and S-wave velocities, respectively.

Assuming the tested shale samples to be transversely isotropic (TI), five different velocity measurements are required to derive the five independent elastic constants (see Appendix A for further detail). Measurements of velocity corresponding to $\mathrm{P}$ - and $\mathrm{S}$-waves propagating perpendicular and parallel to layering and also measuring velocity of a $\mathrm{P}$-wave propagating at $45^{\circ}$ with respect to the layering are required to describe a TI medium. As sketched schematically in Figure $3 \mathrm{a}, V_{\mathrm{P} 0}$ and $V_{\mathrm{S} 0}$ are the velocities related to the $\mathrm{P}$ - and $\mathrm{S}$-waves propagating along the axis of symmetry (perpendicular to the layering), respectively. The $V_{\mathrm{P} 90}$ is defined as the velocity for the $\mathrm{P}$-wave measured normal to the symmetry axis (parallel to the layering). Also, $V_{\mathrm{SH} 90}$ is the velocity of the S-wave propagating perpendicular to the symmetry axis (parallel to the layering) with polarization parallel to the layering. In addition, $V_{\mathrm{P} 45}$ is the velocity of the $\mathrm{P}$-wave measured either axially or radially on the core plugs drilled $45^{\circ}$ to the layering (Figure 3a).

Many authors have discussed whether the measured velocities in the laboratory are of group or phase velocity (Dellinger and Vernik, 1994; Hornby, 1998; Dewhurst and Siggins, 2006; Sarout and Guéguen, 2008a). When the wave propagation direction is perpendicular to the layering, and also for wave propagation in any azimuth of the horizontal plane, the group and phase velocities coincide. However, the measured velocity at off-axis directions (e.g., $45^{\circ}$ to the layering) could be group velocity, phase velocity, or something in between. The experimental setup used in this study measures the velocity $45^{\circ}$ to the layering in the same way as was done by Vernik and Nur (1992) and Hornby (1998). According to Auld (1973), if the transducers are very small compared with their separation, the traveltimes likely measure the group velocity. In

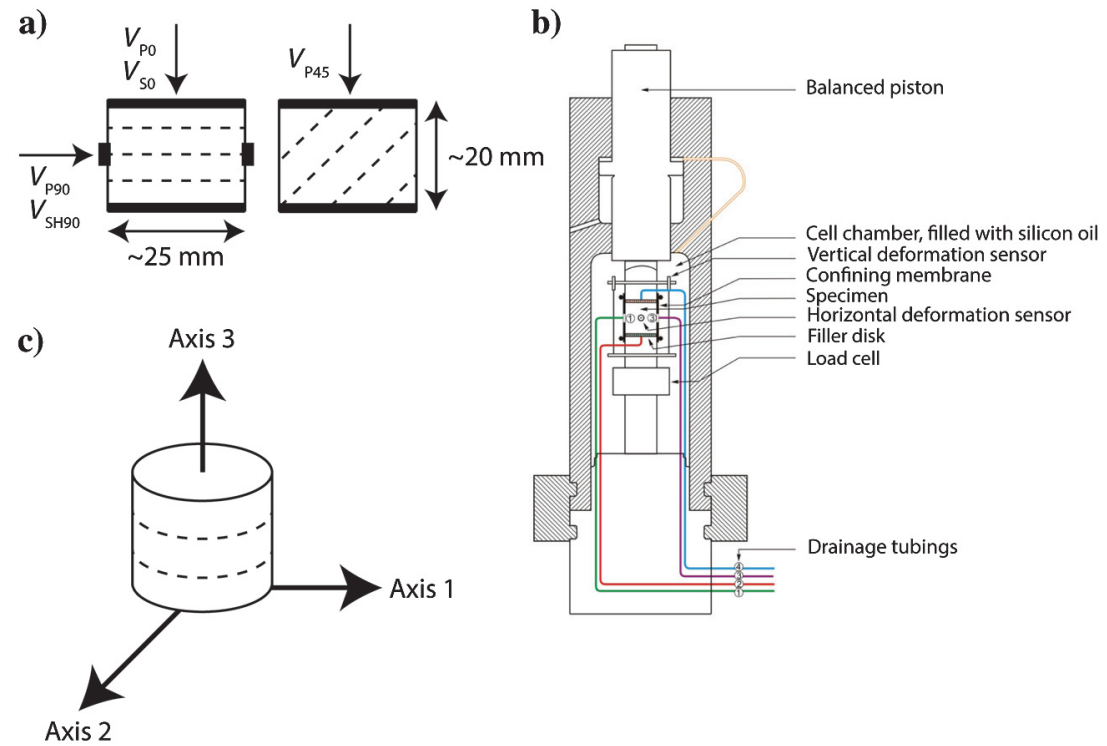

Figure 3. (a) Schematic diagram of the tested samples in the triaxial cell and the transducer arrangement around the samples. (b) Schematic diagram of the vertical cross section through the triaxial experimental setup (with courtesy of NGI). (c) A schematic sketch of the sample cut perpendicular to layering and the three spatial axes. Axis 3 lies along the axis of rotational symmetry of the sample.

Table 2. Physical and geochemical properties of the shale samples used in this study.

\begin{tabular}{|c|c|c|c|c|c|c|c|c|}
\hline \multirow[t]{2}{*}{ Shale } & \multicolumn{2}{|c|}{$\operatorname{Depth}^{3}(\mathrm{~m})$} & \multicolumn{4}{|c|}{ Physical properties } & \multicolumn{2}{|c|}{ Geochemical properties } \\
\hline & RKB & BSF & $\begin{array}{c}\text { Bulk density }{ }^{4} \\
\left(\mathrm{~g} / \mathrm{cm}^{3}\right)\end{array}$ & $\begin{array}{c}\text { Total porosity } \\
(\%)\end{array}$ & $\begin{array}{l}\text { Grain density } \\
\left(\mathrm{g} / \mathrm{cm}^{3}\right)\end{array}$ & $\begin{array}{c}\text { Water content } \\
(\%)\end{array}$ & TOC (wt. \%) & HI (mg HC/g TOC) \\
\hline Draupne & 2582.25 & 2485 & 2.237 & 9.4 & 2.5 & 8 & 6.8 & 531 \\
\hline Hekkingen & 1365.11 & 1090 & 2.065 & 7.8 & 2.3 & 4 & 19.4 & 327 \\
\hline
\end{tabular}

\footnotetext{
${ }^{3}$ The values reported here are measured depths referenced from the RKB and bottom sea floor (BSF).

${ }^{4}$ These values are measured or calculated at ambient pressure and temperature conditions.
} 
contrast, the traveltimes represent the phase velocity if the transducers are relatively wide compared with their separation. For the shale samples tested by Vernik and Nur (1992), the separation between the transducers was more than three times greater than the transducers width and consequently, measurement of group velocity is more likely expected in this case. Dellinger and Vernik (1994) make a numerical model of pulse-transmission experiments carried out by Vernik and Nur (1992), and show that the P-wave velocity measured at $45^{\circ}$ to the layering in their tests was indeed phase velocity with less than $1 \%$ error. Hornby (1998) made the same conclusion about the velocity measurements at off-axis angles of his tested shale samples. Therefore, phase velocities are directly measured when the transducers are located at the flat ends of the cylindrical sample cut $45^{\circ}$ to the layering if the critical ratio of the sample height to transducer width is not at most greater than three (Dellinger and Vernik, 1994).

The core plug cut vertical to layering was primarily compacted in the triaxial cell in unsaturated condition under anisotropic stress until the horizontal stress $\left(\sigma_{\mathrm{h}}\right)$ was $17 \mathrm{MPa}$ and the vertical stress $\left(\sigma_{\mathrm{v}}\right)$ was $26 \mathrm{MPa}$, giving a $K_{0}\left(\sigma_{\mathrm{h}} / \sigma_{\mathrm{v}}\right)$ value of 0.65 . This condition represents the in situ condition of the specimen. Afterward, the specimen was saturated with brine containing $37,000 \mathrm{ppm} \mathrm{NaCl}$ by applying pore pressure up to $30 \mathrm{MPa}$ while keeping the effective horizontal and vertical stresses constant. Then, a $K_{0}$ consolidation stress was applied with a constrained rate of vertical strain equivalent to $0.0091 \mathrm{mS} / \mathrm{h}$ (milistrain $[\mathrm{mS}$ ] is defined as strain value

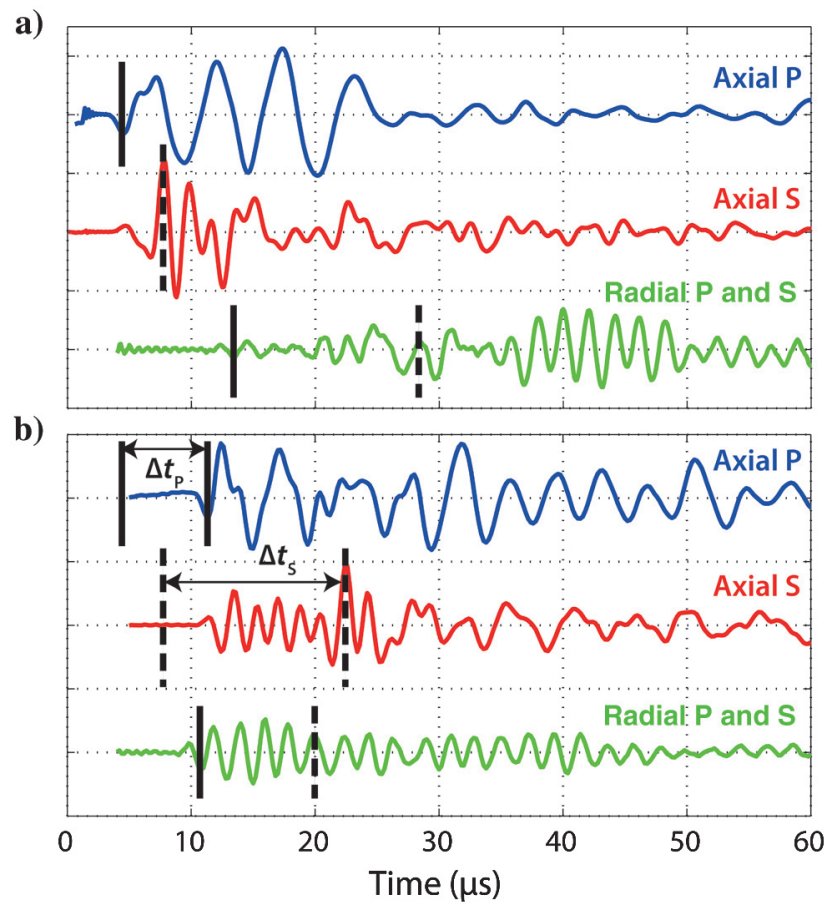

Figure 4. (a) The reference P-wave (blue) and S-wave (red) signals recorded in the axial direction at head-to-head configuration under $20 \mathrm{MPa}$ applied vertical stress and the reference waveform acquired in the radial direction (green) through a dummy sample with known velocity measured at $20 \mathrm{MPa}$ radial stress. (b) Representative recorded signals from the brine-saturated compaction test of the Hekkingen shale sample acquired at $45 \mathrm{MPa}$ vertical effective stress. The first-arrival time picks on the waveform are marked by the black solid and dashed lines for the P-and S-waves, respectively. times 1000). The $K_{0}$ consolidation involves confining pressure to keep radial dimensions unchanged (radial strain equal to zero) whereas deviatoric vertical stress establishes a progressive vertical strain with a constant rate. The strain rate should be set as a small value $(0.0091 \mathrm{mS} / \mathrm{h})$ to avoid any sudden failure in the sample due to axial loading. Moreover, the low strain rate prevents the occurrence of pore pressure buildup in the consolidation stage due to the low permeability. Consequently, their pore pressure is very susceptible to pore volume reduction. The value of strain rate applied in this study is calculated based on the measured permeability and length of the specimen according to the equation established by Wissa et al. (1971). Figure 5 shows the testing protocol of core plugs cut perpendicular to layering.

The triaxial cell used to carry out the tests in this study is not capable of measuring velocity in the diagonal direction. Thus, the core plugs cut vertical to layering cannot be used to measure the velocity of the P-wave propagation inclined to layering. Then, a core plug cut at $45^{\circ}$ inclined to the layering is used to measure $\mathrm{P}$ wave velocity at $45^{\circ}$ to the layering. This core plug was initially compacted under hydrostatic pressure to $20 \mathrm{MPa}$ and then saturated with the same brine by applying $30 \mathrm{MPa}$ back pressure while keeping the effective stress constant as $20 \mathrm{MPa}$. The specimen was further hydrostatically pressured to $34 \mathrm{MPa}$ effective confining pressure, which is the ultimate capacity of the apparatus.

All the tests, either $K_{0}$ consolidation or isotropic loading, were performed in a drained condition keeping the pore pressure constant at $30 \mathrm{MPa}$. This high pore pressure helps to better saturate the lowpermeability shale samples. The pore pressure was controlled by applying back pressure on the specimen and allowing the excess pore water to expel from the specimen from a drainage outlet at the bottom of the specimen. A pore pressure sensor was used to constantly monitor the pore pressure at the bottom of the specimen.

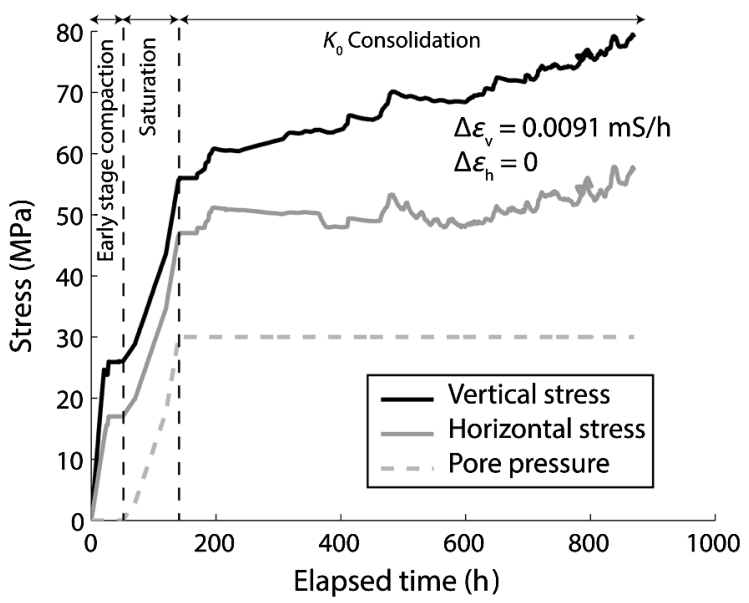

Figure 5. The loading pass and test progress with elapsed time for a core plug (the Draupne sample) cut vertical to the bedding. The sample was primarily compacted in the triaxial cell in an unsaturated condition under anisotropic stress until the horizontal stress was $17 \mathrm{MPa}$ and the vertical stress was $26 \mathrm{MPa}$. The sample was saturated with brine by applying pore pressure up to $30 \mathrm{MPa}$ while keeping the effective horizontal and vertical stresses constant. Then, a $K_{0}$ consolidation stress was applied with a constrained rate of vertical strain equivalent to $0.0091 \mathrm{mS} / \mathrm{h}$. 


\section{RESULTS}

\section{Stress-strain relationship}

During the first phase of compaction simulating the in situ pressure conditions, the unsaturated samples experienced small deformations in the vertical and horizontal directions. Figure 6 a shows the amount of strain observed in both samples in response to increasing the vertical and horizontal stresses. The samples show similar strain in the axial and radial directions indicating almost the same level of stiffness for the two samples. Both samples deform less than $3 \mathrm{mS}$ in the radial direction and approximately $7-8 \mathrm{mS}$ in the axial direction (Figure 6a). During the $K_{0}$ consolidation test, the brine-saturated samples show even higher stiffness and less compaction (Figure 6b). The Hekkingen shale shows less than $4 \mathrm{mS}$ deformation in the axial direction (the open diamonds in Figure 6b), whereas the Draupne shale deforms almost $7 \mathrm{mS}$ in the axial direction (the filled diamonds in Figure 6b). As expected, the radial de-

\section{a) Early stage compaction-unsaturated condition}

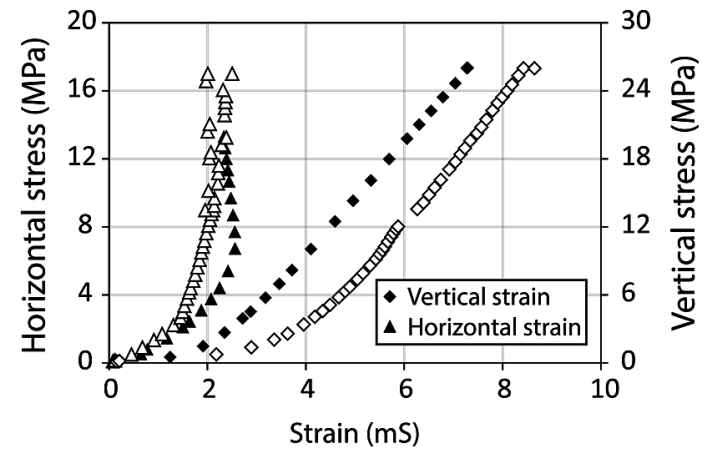

b) $K_{0}$ consolidation phase-saturated condition

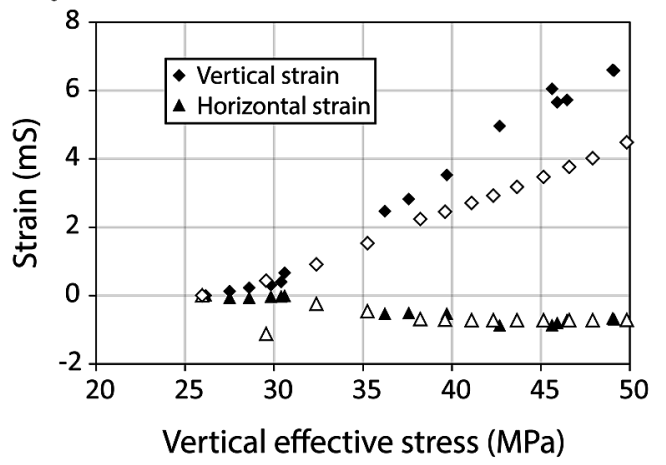

Figure 6. (a) Strain variation as a function of applied stress in the horizontal (radial) and vertical (axial) directions for the Draupne (filled data points) and Hekkingen (open data points) core plugs cut perpendicular to the bedding. The samples during the early stage compaction are in unsaturated condition to reach the original in situ overburden stress. Both samples show almost the same horizontal strain (triangles) in response to increasing horizontal stress. The vertical strain (diamonds) is larger for the Hekkingen sample than the Draupne sample at the same vertical stress level. (b) Strain variation as a function of vertical effective stress in the horizontal (radial) and vertical (axial) directions for the Draupne (filled data points) and Hekkingen (open data points) core plugs cut perpendicular to the bedding during $K_{0}$ consolidation in saturated condition under drained pore pressure control. The unit of strain is $\mathrm{mS}$ (milistrain $[\mathrm{mS}]$ which is defined as strain value times 1000). formation is approximately constant and is kept close to zero during $K_{0}$ consolidation (triangles in Figure $6 \mathrm{~b}$ ).

Variations in the $K_{0}\left(\sigma_{\mathrm{h}} / \sigma_{\mathrm{v}}\right)$ values during the $K_{0}$ consolidation phase reflect a different behavior of the two studied shales at different stress levels. For both samples, $K_{0}$ starts to decrease first (Figure 7). The vertical effective stress increases constantly during the test, whereas the horizontal effective stress is controlled in response to radial deformation. The horizontal effective stress remains at a constant plateau until the vertical effective stress reaches 45 and $37 \mathrm{MPa}$ for the Draupne and Hekkingen samples, respectively (Figure 7). The $K_{0}$ parameter decreases before these stress levels are reached (Figure 7). The $K_{0}$ starts to increase gently beyond these vertical effective stress levels because the horizontal effective stress increases to keep the diameter of the sample unchanged (Figure 7). This indicates a tendency of the material to expand radially at high vertical effective stresses.

\section{Velocity and elastic constants}

The velocities measured in different directions with respect to the bedding plane reflect the anisotropy of both shales. Because the ultrasonic velocity measurements for each shale sample were carried out on two different core plugs with two different stress regimes, the mean effective stress was used to compare the velocity measured along the different layering directions. The mean effective stress $\left(\sigma_{\mathrm{m}}\right)$ is defined as

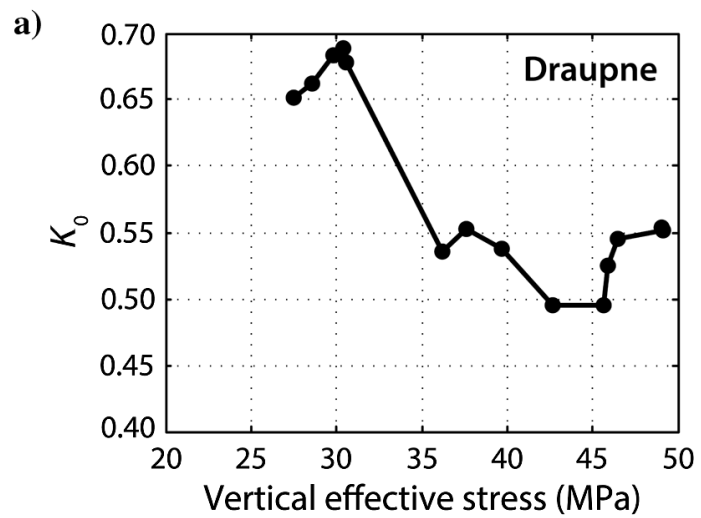

b)

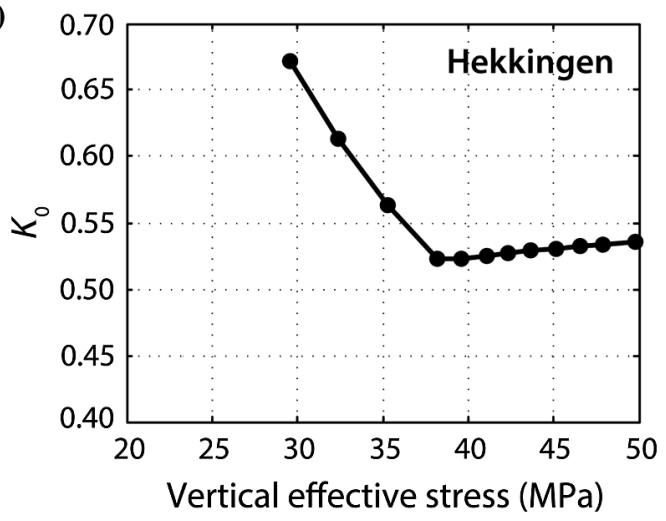

Figure 7. The $K_{0}$ value development as a function of vertical effective stress for the (a) Draupne and (b) Hekkingen core plugs cut perpendicular to the bedding. 


$$
\sigma_{m}=\frac{\sigma_{v}+2 \sigma_{h}}{3}
$$

Figure 8 shows the measured velocities versus mean effective stress for the Draupne and the Hekkingen shale samples. At relatively lower mean effective stress levels, the velocities measured in unsaturated samples increase with increasing the mean effective stress (Figure 8). The velocities measured in the unsaturated condition for the Hekkingen sample show a nonlinear trend for a mean effective stress range from 0 to $20 \mathrm{MPa}$ indicating a higher rate of velocity increase at lower mean effective stress levels. In contrast, the unsaturated Draupne shale core plug shows a linear velocitystress relation at very low effective stress levels. For the Draupne shale, $V_{\mathrm{P} 0}$ increases from approximately 2600 to $2800 \mathrm{~m} / \mathrm{s}$ (Fig-

a)
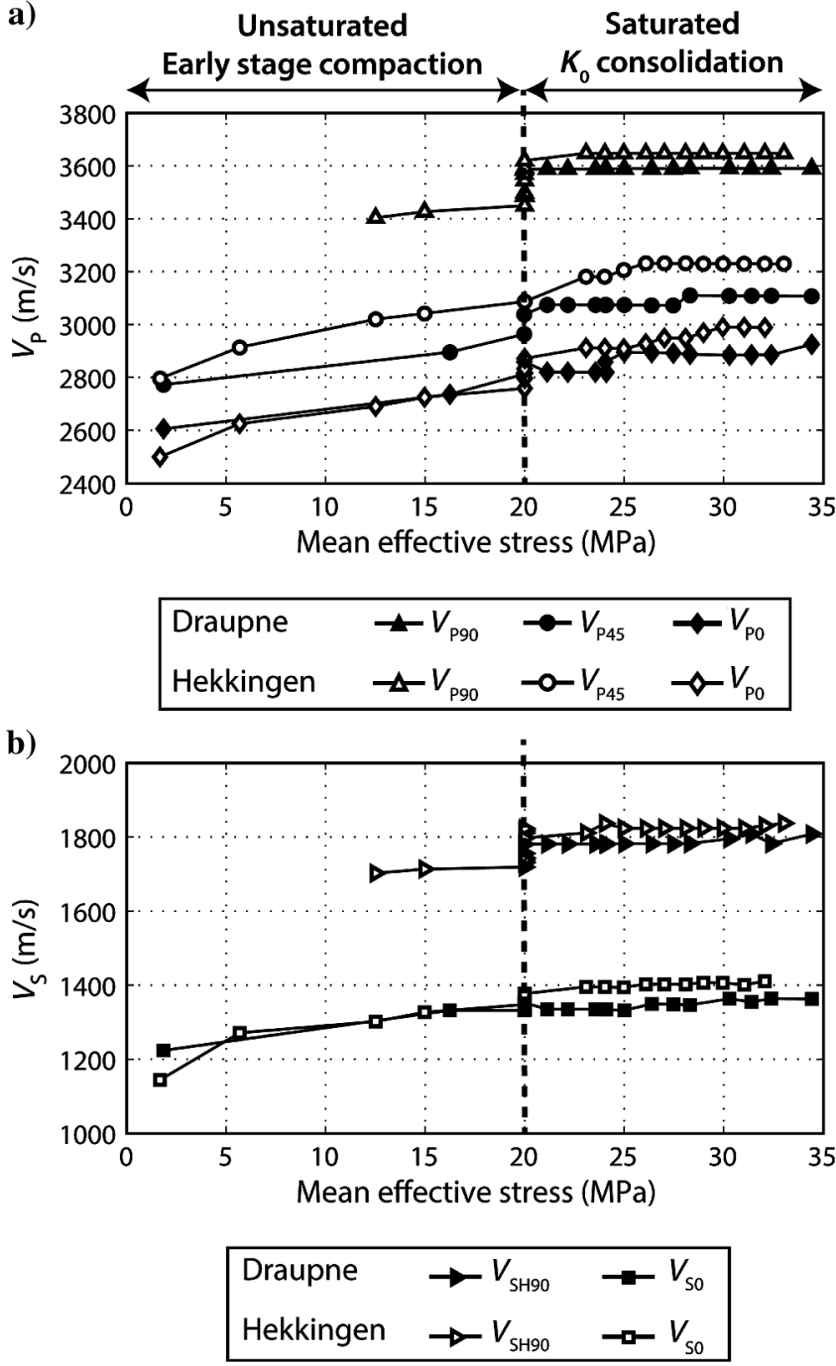

Figure 8. The (a) $V_{\mathrm{P}}$ and (b) $V_{\mathrm{S}}$ measured for the Draupne (filled data points) and Hekkingen (open data points) shale samples plotted versus mean effective stress. The saturated Hekkingen core plug shows slightly larger velocity than the Draupne shale. The definitions of velocities $\left(V_{\mathrm{P} 0}, V_{\mathrm{S} 0}, V_{\mathrm{P} 90}, V_{\mathrm{SH} 90}\right.$, and $\left.V_{\mathrm{P} 45}\right)$ are visually presented in Figure $3 \mathrm{a}$. Notice that $V_{\mathrm{SH} 90}$ is the shear velocity measured parallel to the bedding with polarization also parallel to the bedding. ure 8a) and $V_{\mathrm{S} 0}$ increases from approximately 1200 to $1300 \mathrm{~m} / \mathrm{s}$ (Figure 8b) as the mean effective stress increases from 2 to $20 \mathrm{MPa}$. The Hekkingen shale shows relatively lower velocity values at lower stress levels compared with the Draupne shale. In the Hekkingen sample, $V_{\mathrm{P} 0}$ increases from approximately 2500 to $2800 \mathrm{~m} / \mathrm{s}$ and $V_{\mathrm{S} 0}$ increases from approximately 1100 to $1300 \mathrm{~m} / \mathrm{s}$ along the 2-20 MPa mean effective stress interval. In the two shales, $V_{\mathrm{P} 90}$ and $V_{\mathrm{SH} 90}$ show much higher values compared with their counterparts measured along the axis of symmetry. $V_{\mathrm{P} 45}$ lies between $V_{\mathrm{P} 0}$ and $V_{\mathrm{P} 90}$ (Figure $8 \mathrm{a}$ ). The Hekkingen core plug shows higher $V_{\mathrm{P} 45}$ than the Draupne core plug indicating a nonlinear increase of velocity trend from approximately 2800 to $3350 \mathrm{~m} / \mathrm{s}$ as mean effective stress increases from 2 to $20 \mathrm{MPa}$. In contrast, $V_{\mathrm{P} 45}$ for the Draupne shale increases linearly with smaller rate of velocity increase (Figure 8a).

The samples became saturated at a mean effective stress equivalent to $20 \mathrm{MPa}$ keeping the vertical and horizontal effective stresses constant and allowing creep to take place. During $K_{0}$ consolidation of the saturated samples between 20 and $34 \mathrm{MPa}$ mean effective stress, the measured velocities increase steadily for both shales. In general, the saturated Hekkingen sample shows higher velocities than the saturated Draupne sample during the $K_{0}$ testing phase (Figure 8). The $V_{\mathrm{P} 0}$ varies from approximately 2800 to $2900 \mathrm{~m} / \mathrm{s}$ when the mean effective stress increases from 20 to $34 \mathrm{MPa}$, whereas $V_{\mathrm{P} 0}$ for the Hekkingen sample, it is approximately $100 \mathrm{~m} / \mathrm{s}$ higher than the Draupne sample within the same mean effective stress range. As expected for a TI medium, $V_{\mathrm{P} 90}$ and $V_{\mathrm{SH} 90}$ show higher values compared with $V_{\mathrm{P} 0}$ and $V_{\mathrm{S} 0}$, respectively. However, the measured velocities along the radial direction stay constant increasing only by $5 \mathrm{~m} / \mathrm{s}$ when the mean effective stress is increased from 20 to $34 \mathrm{MPa}$ (Figure 8). Along the same effective stress interval, $V_{\mathrm{P} 45}$ varies from approximately 3000 to $3100 \mathrm{~m} / \mathrm{s}$ for the Draupne sample and from approximately 3100 to $3200 \mathrm{~m} / \mathrm{s}$ for the Hekkingen sample (Figure 8a).

The elastic constants, $\mathrm{C}_{11}, \mathrm{C}_{33}, \mathrm{C}_{44}$, and $\mathrm{C}_{66}$ were calculated based on the velocity measurements achieved for the vertical core plug under the $K_{0}$ consolidation test (equations A-2-A-6 in Appendix A). Also, these parameters along with the $V_{\mathrm{P}}$ measurement of the isotropic test on the core plug cored at $45^{\circ}$ to the layering determine the elastic constant $\mathrm{C}_{13}$. However, the calculated values of $\mathrm{C}_{13}$ in this study may carry some degree of uncertainty due to the differences in the deviatoric stress states experienced by the core plugs cut either perpendicular or $45^{\circ}$ to bedding. The trends of the calculated elastic constants as a function of mean effective stress are plotted in Figure 9. The elastic constants related to S-wave velocity $\left(\mathrm{C}_{44}\right.$ and $\left.\mathrm{C}_{66}\right)$ are almost equivalent for both tested shales. In contrast, the $\mathrm{P}$-wave elastic constants $\left(\mathrm{C}_{11}\right.$ and $\left.\mathrm{C}_{33}\right)$ for the Draupne shale show slightly higher values than for the Hekkingen shale (Figure 9). This means the bulk density of the Draupne shale is large enough to compensate for the effect of higher $V_{\mathrm{P}}$ values in the Hekkingen sample.

Thomsen's (1986) anisotropy parameters $(\varepsilon, \gamma$, and $\delta)$ calculated from equations A-7 to A-9 (Appendix A) are plotted as a function of the mean effective stress in Figure 10. By increasing the mean effective stress, epsilon $(\varepsilon)$ and gamma $(\gamma)$ decrease. The reduction of anisotropy is more evident for $\varepsilon$ because it decreases from 0.31 to 0.25 for the Draupne sample and from 0.28 to 0.24 for the Hekkingen sample when the mean effective stress increases from 20 to $34 \mathrm{MPa}$ (Figure 10a). No significant difference can be observed 
between the Draupne and Hekkingen shales for $\varepsilon$ and $\gamma$, meaning that these shales show almost the same amount of $V_{\mathrm{P}}$ and $V_{\mathrm{S}}$ anisotropy (Figure 10a and 10b). The calculated delta $(\delta)$ values show lower values compared with the other anisotropy parameters (Figure 10c); however, some degree of uncertainty may exist for the calculated $\delta$ values in this study due to probable uncertainties for calculated $\mathrm{C}_{13}$ values. The $\delta$ values calculated for the Hekkingen shale are all positive, whereas the Draupne sample shows $\delta$ close to zero and negative values (Figure 10c).

\section{DISCUSSION}

\section{Velocity variations with effective stress}

As expected, the measured velocities $\left(V_{\mathrm{P}}\right.$ and $V_{\mathrm{S}}$, axial and radial) increase as a function of the increasing mean effective stress in both shales (Figure 8). At low mean effective stress levels (2$20 \mathrm{MPa}$ ), velocity increase in unsaturated samples shows linear (in the Draupne sample) and nonlinear (in the Hekkingen sample) trends in response to the stress increase (Figure 8). The nonlinearity in velocity-effective stress trends have previously been reported for dry or unsaturated shale tests (e.g., Johnston, 1987; Johnston and Christensen, 1995; Vernik and Landis, 1996; Hornby, 1998; Sarout and Guéguen, 2008a). However, this type of nonlinear trend was also observed in the saturated condition (Jakobsen and Johansen, 2000; Dewhurst et al., 2011; Sarout et al., 2014). Beside the nonlinear trend of velocity-effective stress trends at low effective stress levels, some authors show less sensitivity of velocity to effective stress by observing a linear relationship between these two parameters even at low effective stress levels (Vernik and Nur, 1992; Ver-

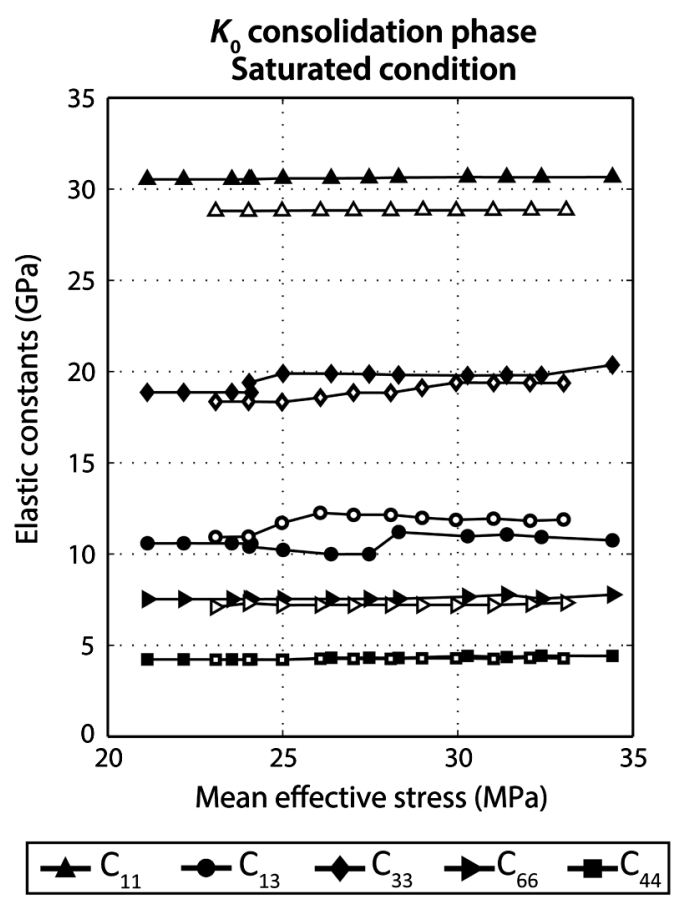

Figure 9. The elastic stiffness constants calculated for the Draupne (filled data points) and Hekkingen (open data points) shale samples plotted versus mean effective stress during saturated consolidation of the samples under drained pore pressure control. nik and Landis, 1996; Dewhurst and Siggins, 2006; Sondergeld and Rai, 2011). Rai and Hanson (1988) document a small pressure dependence of the velocity values measured in fresh and well-preserved shale cores. Similar behavior is observed for the measured velocities in the Draupne shale which is collected from a relatively fresh core (acquired in 2013). When the core is taken out from its in situ condition and to the surface, the overburden pressure is released from around the core resulting in opening of preexisting fractures and generating some microfractures along the layering. The nonlinear relationship between velocity and effective stress at low effec-

a)

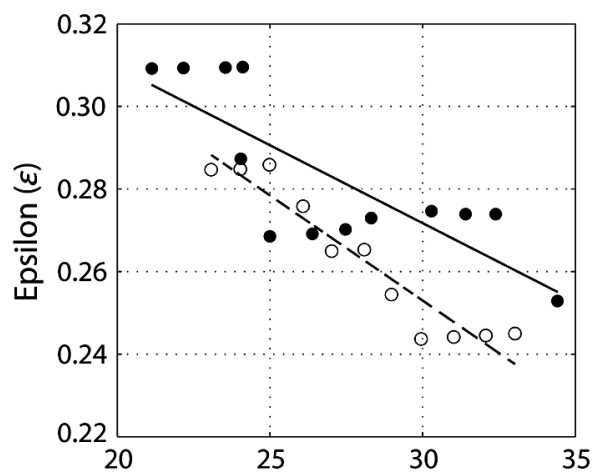

b)

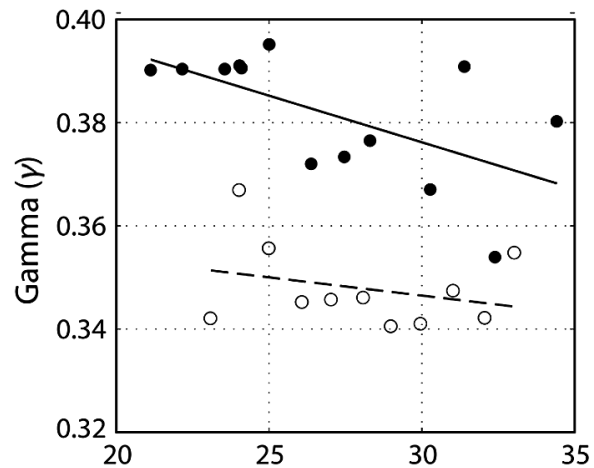

c)

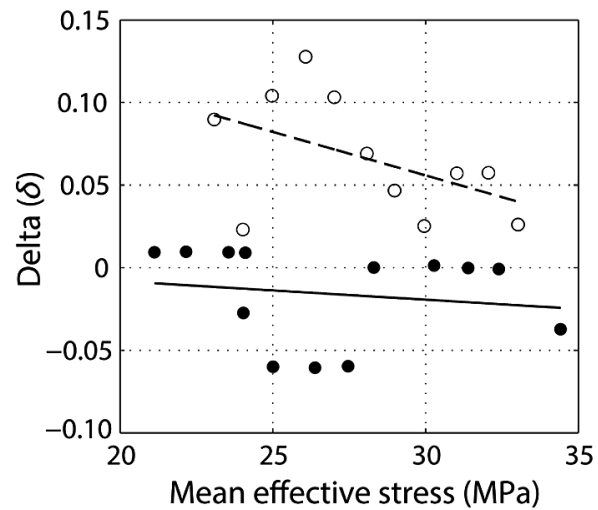

\begin{tabular}{clcl|}
\hline Draupne data & $\circ$ & Hekkingen data \\
Fitted line & --- & Fitted line \\
\hline
\end{tabular}

Figure 10. Thomsen's (1986) anisotropy parameters versus mean effective stress: (a) $\varepsilon$, (b) $\gamma$, and (c) $\delta$ were calculated based on the elastic stiffness constants (equations A-7-A-9) for saturated core plugs of the Draupne (filled circles) and the Hekkingen (open circles) shales. 
tive stresses can be attributed to the soft matrix of the rock. The stiffness of the rock matrix and its constituent grains can determine the trend of velocity increase at low effective stress levels. The vertical strain versus vertical effective stress plot (diamonds in Figure 6a) indicates the rock compressibility in both samples. As stress is applied on the rock, some nonlinearity is observed in the stress-strain plot (Figure 6a). Larger deformation is observed for the Hekkingen shale (the open diamonds in Figure 6a) compared with the Draupne sample (the filled diamonds in Figure 6a) at the same level of vertical effective stress. The larger deformation of the Hekkingen sample suggests a softer rock matrix in this sample. Figure 11 shows the microscopic images taken perpendicular to the layering of the tested core plugs at an ambient pressure condition. The images shown in Figure 11 were taken in the same conditions by the conventional back-scattering scanning electron microscopy (SEM). It is evident that the Hekkingen sample contains more organic matter than the Draupne sample. TOC measurements through routine geochemical analysis support this observation, too. The organic materials within the shale samples are aligned along the layering perpendicular to the principal applied stress (Figure 11). In addition, SEM images of the samples show stress-relief cracks and fractures propagated parallel to the layering (the red arrows in Figure 11a). When the stress is applied from the vertical and radial directions, the softer organic matter is compacted and stressrelief fractures close. After this early compaction, the sample shows a linear trend of velocity increase with the increasing effective stress.

In addition to the effects related to the rock matrix stiffness, the maturity of the organic matter embedded in the shale samples may also influence the velocity behavior in response to the increasing

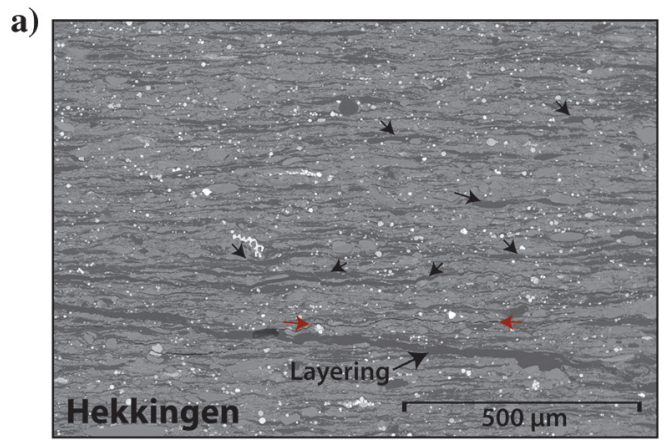

b)

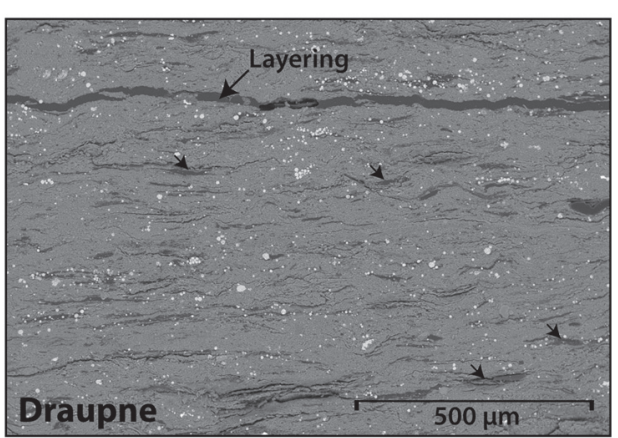

Figure 11. SEM images taken in the direction of vertical to layering for the (a) Hekkingen and (b) Draupne core plugs at ambient pressure condition. The black arrows show some examples of embedded organic matter in both samples. The red arrows in the top frame correspond to a stress-relief microfracture in the sample. effective stress (Vernik and Nur, 1992; Vernik and Landis, 1996). According to Tissot and Welte (1978), HI values greater than $500 \mathrm{mg} \mathrm{HC} / \mathrm{g}$ TOC correspond to early stages of organic matter maturation. This means that the Draupne Formation with HI value of $550 \mathrm{mg} \mathrm{HC} / \mathrm{g}$ TOC may not have yet entered the oil window. In contrast, the Hekkingen sample with $\mathrm{HI}$ values of approximately $300 \mathrm{mg} \mathrm{HC} / \mathrm{g}$ TOC is within the main stage of hydrocarbon generation and also primary hydrocarbon migration. HI shows that some of the embedded organic matter in the Hekkingen Formation has been transformed into oil that has possibly migrated out of the formation. The experimental results presented by Vernik and Nur (1992) and Vernik and Landis (1996) on a set of organic-rich shale samples with different kerogen content and maturity revealed that the immature or early mature organic-rich shales show a more linear velocity-effective stress relationship when the sample is dry or unsaturated. In contrast, the orthogonal-to-layering velocity measurements of hydrocarbon-generating shales, such as the Hekkingen in this study, are more sensitive to the effective stress and show a nonlinear velocity-effective stress trend at lower stresses.

\section{Velocity relationship with exhumation, organic content, and total porosity}

As already presented in Figure 8, the velocities associated with the brine-saturated Hekkingen sample measured perpendicular, parallel, and at $45^{\circ}$ relative to the layering are relatively higher than those of the saturated Draupne sample. The differences in corresponding velocity values measured for the Draupne and Hekkingen shales are not significant $(<100 \mathrm{~m} / \mathrm{s})$. Burial depth and temperature are the most important parameters governing the degree of compaction in siliciclastic rocks. The burial depth of the tested Draupne and Hekkingen shale samples are approximately 2485 and $1090 \mathrm{~m}$ below seafloor (m BSF), respectively (NPD, 2015). Adding the amount of Cenozoic uplift (approximately $1300 \mathrm{~m}$ ) to the burial depth of the Hekkingen shale gives approximately a total of $2390 \mathrm{~m}$ BSF maximum burial depth for this sample. The bottom hole temperature measurements adopted from NPD (2015) reveal geothermal gradients equivalent to $33.4^{\circ} \mathrm{C}$ and $31.2^{\circ} \mathrm{C} / \mathrm{km}$ at the locations of the wells 16/8-3S (in the North Sea, penetrating the Draupne Formation) and 7125/1-1 (in the Barents Sea, penetrating the Hekkingen Formation), respectively. Furthermore, the uplifted Barents Sea basin probably shows a higher geothermal gradient at the present time because the Cenozoic uplift and erosion of sediments may increase the heat flux from deeper rocks (Bjørlykke, 2010). This may indicate that the Barents Sea region has experienced a lower paleo-geothermal gradient than at the present time. Overall, the sample from the Draupne Formation most likely has been buried deeper and at a higher temperature than the Hekkingen Formation sample.

In addition to the burial depth and temperature, the tested samples are also different with respect to the amount of TOC content embedded in their texture (Table 2), although deposited in similar conditions. The occurrence of low-density kerogen in shales softens the rock and decreases its bulk density (Vernik and Nur, 1992; Vernik and Liu, 1997). The lower TOC content in the Draupne shale (6.8\%) compared with the Hekkingen shale $(19.4 \%)$ in parallel with a somewhat deeper burial depth and higher geothermal gradient of the Draupne Formation should produce a higher velocity.

Total porosity is another important parameter controlling the velocity in rocks. The measured axial $V_{\mathrm{P}}$ versus total porosity 
for the two tested shale samples during the initial compaction phase (when the samples are still unsaturated) is shown in Figure 12. The Hekkingen sample has a lower total porosity than the Draupne sample. It can also be inferred from the lower water content of the Hekkingen core plug (approximately 4\%) compared with the Draupne core plug (approximately 8\%). The Hekkingen shale contains much more soft low-density organic matter than the Draupne sample. At the time of deposition of the Hekkingen Formation, the higher content of organic matter made the Hekkingen sediments very soft and susceptible to more porosity reduction in response to mechanical loading compared with the Draupne Formation.

For the unsaturated samples during the first phase of anisotropic loading, the variation of $V_{\mathrm{P} 0}$ with total porosity shows a negative curvature in the Draupne sample (Figure 12b), whereas the $V_{\mathrm{P} 0}$ porosity trend shows a positive curvature in the Hekkingen sample (Figure 12a). The behavior of the velocity-porosity relationship in the Draupne sample means that porosity reduction at an early stage of compaction does not affect the velocity values much. At this stage, the porosity reduction results in closer grain packing without much stiffening of the grain contacts. This can be justified by finer layering of the tested Draupne shale compared with its Hekkingen counterpart. By further loading, the layers of the rock get closer and finally get in contact. The velocity is then increased at a faster rate due to more grain-to-grain contact stiffening. This kind of trend with negative curvature for the Draupne shale expresses the lower pressure sensitivity of the measured velocity in this sample com-
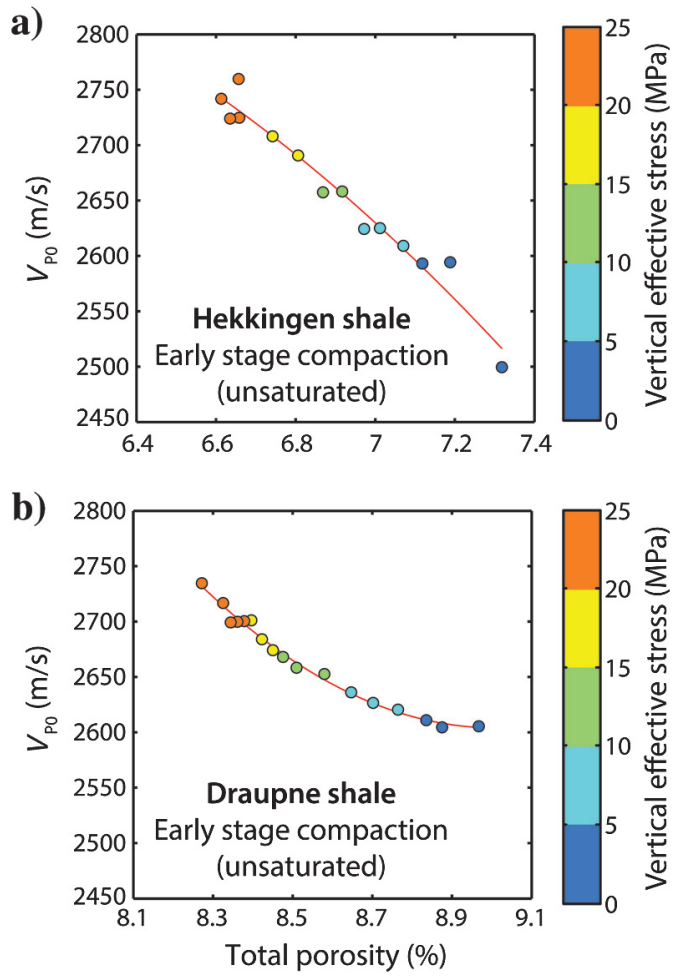

Figure 12. The $V_{\mathrm{P}}$ variation measured perpendicular to bedding $\left(V_{\mathrm{P} 0}\right)$ versus total porosity color coded by vertical effective stress for the (a) Hekkingen and (b) Draupne samples when primarily compacted up to $17 \mathrm{MPa}$ horizontal stress and $26 \mathrm{MPa}$ vertical stress in unsaturated condition during the early stage compaction (notice the difference in scale of the horizontal axes in the two plots). pared with the Hekkingen shale. Initially, the Hekkingen sample shows lower axial $V_{\mathrm{P}}$ than the Draupne sample though it has less total porosity (Figure 12). The Hekkingen sample contains a high degree of organic material aligned along the layering (Figure 11a), which slows down the P-waves normal to the layering. By increasing the effective stress, the low-density soft organic matter compacts resulting in tighter grain-to-grain contacts in the Hekkingen sample and consequently, $V_{\mathrm{P}}$ increases rapidly and overtakes the Draupne sample $V_{\mathrm{P}}$ values at the same effective stress levels (Figure 12). Therefore, the more intense compaction and lower total porosity found in the Hekkingen shale results in higher velocity in this sample compared with the Draupne shale. This can also be seen in the well log measurements of the rock physical properties of the Draupne and Hekkingen formations at in situ conditions (Figure 13). The sonic log acquired in well 7125/1-1 measured higher $V_{\mathrm{P}}$ values for the Hekkingen Formation than the $V_{\mathrm{P}}$ measurements for the Draupne Formation in well $16 / 8-3 \mathrm{~S}$. But both formations show almost the same bulk density range (Figure 13). Because the Hekkingen Formation is more organic-rich than the Draupne Formation, it has lower matrix density. Consequently, more total porosity is expected in the Draupne Formation to show the same range of bulk density as the Hekkingen Formation.

\section{Velocity anisotropy}

The Draupne and Hekkingen Shales show a high degree of anisotropy for $V_{\mathrm{P}}$ and $V_{\mathrm{S}}$ (Figure 14). The difference in anisotropy of the tested samples is not significant, although they are different in terms of organic matter richness and maturity level and have experienced different compaction histories. Assessment of the change in anisotropy parameters allows reconstruction of the rock texture development. The reduction in anisotropy parameters along with the velocity increase, particularly the velocity of the waves propagating perpendicular to the layering, can be attributed to the closing of microcracks and discontinuities as a result of the increasing mean effective stress (Dewhurst and Siggins, 2006; Dewhurst et al., 2011). It is also in agreement with the modeling results reported quantitatively by Sarout and Guéguen (2008b), which show a sig-

Well log data measured at well locations

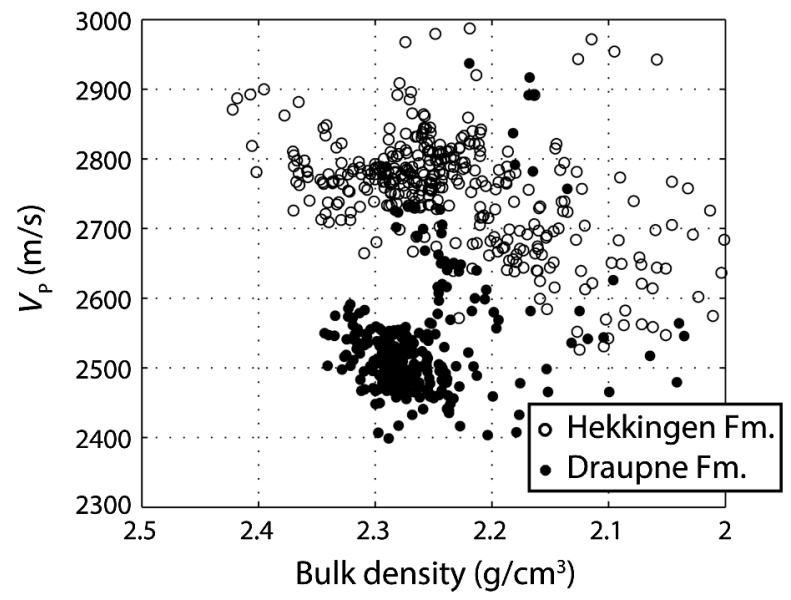

Figure 13. Cross-plot of log-derived $V_{\mathrm{P}}$ versus bulk density for the Draupne and Hekkingen formations penetrated by wells $16 / 8-3 \mathrm{~S}$ and 7125/1-1, respectively. Both wells were drilled vertically. 
nificant decrease of crack density in a brine-saturated shale sample when the confining pressure is increased from 0 to $20 \mathrm{MPa}$.

The values of the anisotropy parameters derived in this study (except $\delta$ ) are close to earlier results from the organic-rich Kimmeridge clay from the British North Sea coast tested by Hornby (1998) (Figure 14). The Kimmeridge clay exhibits almost the same mineralogical composition as the samples tested herein. Also, the anisotropy parameters measured by Wang (2002) for brine-saturated North Sea shales show almost similar values of $\varepsilon$ and $\delta$ as our tested samples, whereas $\gamma$ values in the Wang (2002) data set were lower than the shales tested in this study. The same trend can be observed in shallow-buried clay-rich mudstone core plugs taken from the North Sea tested by Mondol et al. (2010). Mondol et al. (2010) measure velocity anisotropy of two mudstone core plugs, one cut perpendicular to the layering and another $45^{\circ}$ to the layering. Their results show lower $\varepsilon$ and higher $\gamma$ values than the compacted organic-rich shales tested in this study (Figure 14). Moreover, unlike the tested consolidated shales (e.g., this study; Hornby, 1998; Wang, 2002; Dewhurst and Siggins, 2006; Sondergeld and Rai, 2011), the anisotropy of the shallow-buried mudstone increases by increasing the mean effective stress (Mondol et al., 2010; Figure 14). In addition, Mondol (2012) tests the velocity anisotropy development in mechanically com-

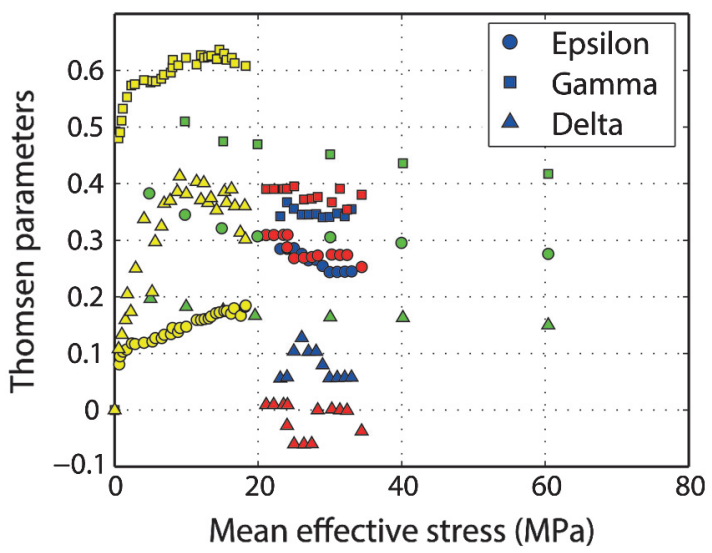

Figure 14. Calculated Thomsen anisotropy parameters versus mean effective stress for the Draupne (red) and Hekkingen (blue) shales tested in this study compared with tests from Mondol et al. (2010) (yellow) and Hornby (1998) (green). a)

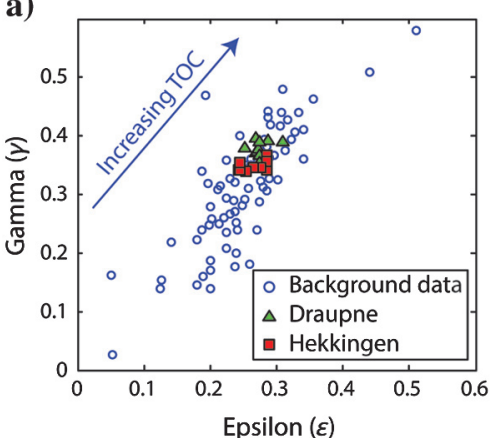

b)

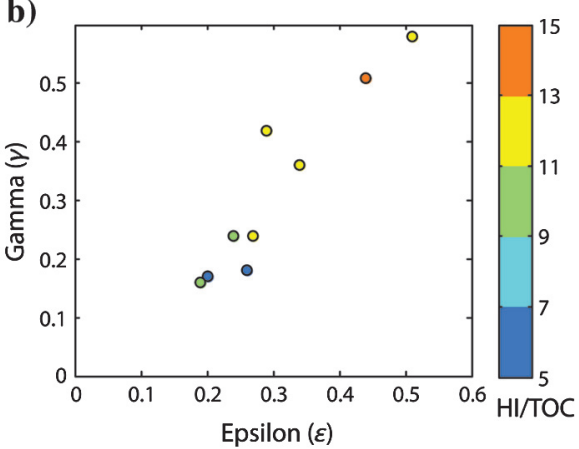

Figure 15. (a) Plot of $\gamma$ versus $\varepsilon$ from the data sets provided by Sondergeld et al. (2000) and Vernik and Nur (1992) overlaid by the data sets achieved for the Draupne and Hekkingen samples tested in this study. (b) The plot of $\gamma$ versus $\varepsilon$ color coded by HI/TOC ratio for the data set from Vernik and Nur (1992). pacted synthetic mixtures of silt and clay with different clay types and clay proportions. According to Mondol's (2012) results, velocity anisotropy increases by increasing the effective stress for clayrich samples, whereas the grain-supported samples with lower clay content showed no clear relationship between velocity anisotropy and further mechanical compaction. Petrographic observations and image analysis of mechanically compacted synthetic samples of silt-clay mixtures taken at different effective stress levels by Fawad et al. (2010) clearly document that clay alignment increases in response to the increasing effective stress for clay-supported samples, whereas no degree of alignment is reported for grain-supported samples. In consolidated shales, however, the total porosity does not vary significantly as a function of the increasing stress. The alignment of clay particles in consolidated shales is almost fixed (Dewhurst and Siggins, 2006) as long as the compaction does not include clay mineral reactions precipitating new clay minerals (e.g., illite formed perpendicular to the principal stress axis). Therefore, unlike the unconsolidated sediments, no clear relationship has been observed between burial compaction and acoustic anisotropy in consolidated rocks. Pervukhina and Rasolofosaon (2015) statistically revisit a compilation of the available data sets on measured velocity anisotropy in shales and find no statistical correlation between anisotropy and burial compaction. Pervukhina and Rasolofosaon (2015) highlight the effect of depositional environment and energy as an important parameter controlling the clay particle alignment and resulting shale anisotropy. As long as the clay alignment is fixed, anisotropy is governed by the crack and microfracture intensity within the rock framework and the amount and maturation of the TOC. The observed anisotropy in organic-rich shales mainly results from the interaction of these three major parameters.

Measurements of anisotropy on many core plugs from organicrich shales with different characteristics reveal a general positive correlation between the anisotropy and amount of organic matter (Vernik and Nur, 1992; Vernik and Landis, 1996; Sondergeld et al., 2000). Plotting the data sets of anisotropy parameters generated in previous studies indicates a background trend for anisotropy of organic-rich shales (plotted as background data in Figure 15a). Also, anisotropy increases when the organic matter begins to mature and generates hydrocarbons until it gets the peak maturation level at the end of the oil and gas window (Vernik and Nur, 1992; Vanorio et al., 2008). The anisotropy parameters derived for the tested organic-rich shales in this study can be seen overlaid on the organic-rich shales background trend in Figure 15a. Although the Draupne sample contains less organic matter and it is less mature compared with the Hekkingen sample, it shows slightly higher anisotropy in contradiction with the background trend expected for organic-rich shales. If only the amount and maturation of the organic matter control anisotropy in organic-rich shales, it would be reasonable to expect some sort of trend between the anisotropy parameters and a factor (such as HI/TOC ratio) including both the amount and maturity of the organic matter. The HI value of organic-rich shales has a reverse relationship with the maturity of the embedded organic matter, so HI is a good indication of the maturation level. Based on this, a decreasing $\mathrm{HI}$ and an increasing TOC and thus, a decreasing HI/TOC 
ratio would be favorable for the increasing anisotropy. Figure $15 b$ shows the anisotropy parameters of organic-rich shales tested by Vernik and Nur (1992) color coded by HI/TOC. Most of the data points with lower HI/TOC exhibit higher anisotropy parameters. However, there are some data points that do not obey this general trend (the same as the organic-rich shales studied herein). This finding indicates the importance of other parameters such as total porosity and microfractures. Unlike the unconsolidated samples, the lower total porosity does not necessarily mean larger anisotropy. The greater anisotropy of the Draupne sample at in situ condition could be mainly due to higher occurrence of microfractures in this sample compared with the Hekkingen sample. Also, rock textural properties such as grain size, sorting, and microfabric can indirectly affect the anisotropy in organic-rich shales. The textural properties of fine-grained particles control the extent of mechanical compaction and porosity reduction before the onset of chemical compaction and quartz cementation (Mondol et al., 2007; Mondol, 2009). The mechanical compaction is important because it determines the intergranular volume at the onset of chemical diagenesis, which is a function of integrated time and temperature.

\section{CONCLUSIONS}

The anisotropy of acoustic velocity was investigated for two organic-rich shales of the Upper Jurassic Draupne and Hekkingen formations taken from the NCS. At an early stage, the unsaturated core plugs were compacted in a triaxial cell to reach their in situ condition and were then saturated with brine by applying back pressure. The saturated samples were then compacted mechanically applying fixed $K_{0}$ consolidation under controlled pore pressure condition. The simultaneous measurements of deformation and acoustic velocity during consolidation help to evaluate the controls on velocity anisotropy in studied organic-rich shales. The following conclusions can be made according to the results of this study:

1) During the early stage of compaction in an unsaturated condition, the Hekkingen shale shows more vertical deformation due to the occurrence of high quantities of low-density soft organic matter aligned parallel to the layering, which comprises almost half of the Hekkingen sample by volume. The susceptibility of the organic material to applied stress results in more compaction of the Hekkingen sample compared with the Draupne shale.

2) The higher TOC content and thermal maturity of the Hekkingen sample lead to a nonlinear velocity-stress trend during compaction of unsaturated specimens. In contrast, the velocities measured for the Draupne shale show less sensitivity to applied stress due to its relatively stiffer framework and also less maturation of its embedded organic matter.

3) The measured velocities in the tested shale samples are almost the same in the three different orientations. Although the maximum burial depth, geothermal gradient, and TOC content of the Draupne shale should produce higher velocities compared with the Hekkingen shale, we observe an opposite behavior due to more compaction and lower porosity of the Hekkingen shale compared with the Draupne shale.

4) Thomsen's anisotropy parameters show a decreasing trend as a function of increasing mean effective stress. For instance, $\varepsilon$ decreases by approximately $20 \%$ for the Draupne sample and by approximately $14 \%$ for the Hekkingen sample when the mean effective stress increases from 20 to $34 \mathrm{MPa}$. The reduction of anisotropy is due to closure of microcracks in well-consolidated shales. Both shale samples show almost the same degree of anisotropy. The Draupne shale shows slightly higher anisotropy compared with the Hekkingen shale, but the difference is not significant. The detection of this small insignificant difference in anisotropy of these tested organic-rich shale samples could be even more difficult in seismic data regarding the low resolution of the seismic wavelength compared with the ultrasonic waves applied in the laboratory.

\section{ACKNOWLEDGMENTS}

The authors are thankful to many NGI personnel for their help and support during the experimental phase. E. Skurveit and L. Grande are highly appreciated for their constructive discussion during the laboratory work and their kind support at NGI supplying and managing the laboratory apparatus used. We are also particularly grateful to S. Vangbæk for preparing undamaged core plugs from the organic-rich shales. T. Berre, R. Otter, M. Soldal, and H. Debreczeny Wilkinson are appreciated for their support to run the experiments at the NGI laboratory. The laboratory of Applied Petroleum Technology AS is thanked for their contribution in the geochemical analysis of the Draupne Shale sample used in this study. S. Akhavan is specially thanked for preparing good qualified thick polished sections to be observed in SEM imaging, and B. Løken Berg is appreciated for her constructive help during SEM analysis. O.Y. Ogebule is thanked for her contribution to sample characterization and also her assistance during the tests. The authors are thankful to M. Aerts, B. Girma Haile, and M. Kalani at the Department of Geosciences for their contribution to the XRD analysis and mineral quantification. D.A. Karlsen and M. Fawad are appreciated for their constructive discussion and comments. The authors express their gratitude to A. Pech Pérez and three anonymous reviewers for their positive spirit that contributed to improving this manuscript by their constructive comments and suggestions. I. Raave, the associate editor of GEOPHYSICS, is highly acknowledged for taking care of this manuscript.

\section{APPENDIX A}

\section{THEORIES RELATED TO VTI MEDIUM}

According to Hooke's law, a vertical transverse isotropic (VTI) medium can be described by five independent elastic constants. Therefore, five different measurements are required to determine the elastic constants. The elastic stiffness tensor can be written in the Voigt notation as follows (Mavko et al., 2009):

$$
\left[\begin{array}{c}
\sigma_{11} \\
\sigma_{22} \\
\sigma_{33} \\
\sigma_{23} \\
\sigma_{13} \\
\sigma_{12}
\end{array}\right]=\left[\begin{array}{cccccc}
\mathrm{C}_{11} & \mathrm{C}_{12} & \mathrm{C}_{13} & 0 & 0 & 0 \\
\mathrm{C}_{12} & \mathrm{C}_{11} & \mathrm{C}_{13} & 0 & 0 & 0 \\
\mathrm{C}_{13} & \mathrm{C}_{13} & \mathrm{C}_{33} & 0 & 0 & 0 \\
0 & 0 & 0 & \mathrm{C}_{44} & 0 & 0 \\
0 & 0 & 0 & 0 & \mathrm{C}_{44} & 0 \\
0 & 0 & 0 & 0 & 0 & \mathrm{C}_{66}
\end{array}\right]\left[\begin{array}{c}
\varepsilon_{11} \\
\varepsilon_{22} \\
\varepsilon_{33} \\
2 \varepsilon_{23} \\
2 \varepsilon_{13} \\
2 \varepsilon_{12}
\end{array}\right] .
$$

In the VTI medium, $\mathrm{C}_{12}$ is not an independent elastic constant and it is calculated as $C_{12}=C_{11}-2 C_{66}$. In equation A-1, axis three lies 
along the axis of rotational symmetry of the sample (Figure 3c). Therefore, $\sigma_{11}$ and $\sigma_{22}$ are normal stresses applied along parallel to layering directions and $\sigma_{33}$ is the normal stress applied toward perpendicular to the layering direction. The parameters $\sigma_{12}, \sigma_{13}$, and $\sigma_{23}$ are the shear stresses; $\mathrm{C}_{i j}$ represents the elastic stiffness constants; $\varepsilon_{11}, \varepsilon_{22}$, and $\varepsilon_{33}$ are the normal strains; and $\varepsilon_{12}, \varepsilon_{13}$, and $\varepsilon_{23}$ are the shear strains. The elastic stiffness constants are related to acoustic velocities measured along the medium in different directions as follows (Mavko et al., 2009):

$$
\begin{gathered}
\mathrm{C}_{11}=\rho V_{\mathrm{P} 90}^{2}, \\
\mathrm{C}_{33}=\rho V_{\mathrm{P} 0}^{2}, \\
\mathrm{C}_{44}=\rho V_{\mathrm{S} 0}^{2}, \\
\mathrm{C}_{66}=\rho V_{\mathrm{SH} 90}^{2}, \\
\mathrm{C}_{13}=-\mathrm{C}_{44} \\
+\sqrt{\left(\mathrm{C}_{11}+\mathrm{C}_{44}-2 \rho V_{\mathrm{P} 45}^{2}\right)\left(\mathrm{C}_{33}+\mathrm{C}_{44}-2 \rho V_{\mathrm{P} 45}^{2}\right)} .
\end{gathered}
$$

To simplify the context of anisotropy in geophysics, Thomsen (1986) expressed five independent elastic constants in terms of three anisotropic parameters:

$$
\begin{gathered}
\varepsilon=\frac{\mathrm{C}_{11}-\mathrm{C}_{33}}{2 \mathrm{C}_{33}}, \\
\gamma=\frac{\mathrm{C}_{66}-\mathrm{C}_{44}}{2 \mathrm{C}_{44}}, \\
\delta=\frac{\left(\mathrm{C}_{13}+\mathrm{C}_{44}\right)^{2}-\left(\mathrm{C}_{33}-\mathrm{C}_{44}\right)^{2}}{2 \mathrm{C}_{33}\left(\mathrm{C}_{33}-\mathrm{C}_{44}\right)},
\end{gathered}
$$

where $\varepsilon$ and $\gamma$ are called the P-wave and S-wave anisotropy parameters, respectively. According to Sarout and Guéguen (2008a), $\varepsilon$ measures the differences in normal stiffness between the vertical and horizontal directions and $\gamma$ measures the differences in shear stiffness between the vertical and horizontal directions. The parameters $\varepsilon$ and $\gamma$ values are always greater than or equal to zero, whereas $\delta$ values can be zero, negative, or positive. Thomsen's parameters are dimensionless, and they reduce to zero in the case of isotropy.

\section{REFERENCES}

Alkhalifah, T., 1996, Transformation to zero offset in transversely isotropic media: Geophysics, 61, 947-963, doi: 10.1190/1.1444044.

Auld, B. A., 1973, Acoustic fields and waves in solids: John Wiley \& Sons Inc.

Baig, I., J. I. Faleide, J. Jahren, and N. H. Mondol, 2016, Cenozoic exhumation on the southwestern Barents Shelf - Estimates and uncertainties constrained from compaction and thermal maturity analyses: Marine and Petroleum Geology, 73, 105-130, doi: 10.1016/j.marpetgeo.2016 .02 .024 .

Birch, F., 1960, The velocity of compressional waves in rocks to 10 kilobars: Part 1: Journal of Geophysical Research, 65, 1083-1102, doi: 10.1029/ JZ065i004p01083.

Bjørlykke, K., 2010, Heat transport in sedimentary basins, in K. Bjørlykke, ed., Petroleum geoscience: From sedimentary environments to rock physics: Springer, 253-257.

Cutts, P. L., 1991, The Maureen Field, Block 16/29a, UK North Sea, in I. L. Abbotts, ed., United Kingdom oil and gas fields, 25 years commemorative volume: Geological Society of London Memoirs 14, 347-352, doi: 10 .1144/GSL.MEM.1991.014.01.43.

Dalland, A., D. Worsley, and K. Ofstad, 1988, A lithostratigraphic scheme for the Mesozoic and Cenozoic succession offshore mid- and northern Norway: Norwegian Petroleum Directorate Bulletin 4.

Delle Piane, C., D. N. Dewhurst, A. F. Siggins, and M. D. Raven, 2011, Stress-induced anisotropy in brine saturated shale: Geophysical Journal International, 184, 897-906, doi: 10.1111/j.1365-246X.2010.04885.x.

Dellinger, J., and L. Vernik, 1994, Do traveltimes in pulse-transmission experiments yield anisotropic group or phase velocities?: Geophysics, 59, 1774-1779, doi: 10.1190/1.1443564.

Dewhurst, D. N., and A. F. Siggins, 2006, Impact of fabric, microcracks and stress field on shale anisotropy: Geophysical Journal International, $\mathbf{1 6 5}$, 135-148, doi: 10.1111/j.1365-246X.2006.02834.x.

Dewhurst, D. N., A. F. Siggins, J. Sarout, M. D. Raven, and H. M. NordgårdBolås, 2011, Geomechanical and ultrasonic characterization of a Norwegian Sea shale: Geophysics, 76, no. 3, WA101-WA111, doi: 10.1190/1 .3569599 .

Doré, A. G., and E. R. Lundin, 1996, Cenozoic compressional structures on the NE Atlantic margin; Nature, origin and potential significance for hydrocarbon exploration: Petroleum Geoscience, 2, 299-311, doi: 10.1144/ petgeo.2.4.299.

Faleide, J. I., S. T. Gudlaugsson, and G. Jacquart, 1984, Evolution of the western Barents Sea: Marine and Petroleum Geology, 1, 123-150, doi: 10.1016/0264-8172(84)90082-5.

Faleide, J. I., R. Kyrkjebø, T. Kjennerud, R. H. Gabrielsen, H. Jordt, S. Fanavoll, and M. D. Bjerke, 2002, Tectonic impact on sedimentary processes during Cenozoic evolution of the northern North Sea and surrounding areas, in A. G. Doré, J. A. Cartwright, M. S. Stoker, J. P. Turner, and N. White, eds., Exhumation of the North Atlantic margin: Timing, mechanisms and implications for petroleum exploration: Geological Society of London, Special Publications 196, 235-269, doi: 10 $.1144 /$ GSL.SP.2002.196.01.14

Faleide, J. I., E. Vågnes, and S. T. Gudlaugsson, 1993, Late Mesozoic-Cenozoic evolution of the south-western Barents Sea in a regional rift-shear tectonic setting: Marine and Petroleum Geology, 10, 186-214, doi: 10 1016/0264-8172(93)90104-Z.

Fawad, M., N. H. Mondol, J. Jahren, and K. Bjørlykke, 2010, Microfabric and rock properties of experimentally compressed silt-clay mixtures: Marine and Petroleum Geology, 27, 1698-1712, doi: 10.1016/j.marpetgeo.2009.10 .002 .

Gabrielsen, R. H., R. B. Færseth, L. N. Jensen, J. E. Kalheim, and F. Riis, 1990, Structural elements of the Norwegian Continental Shelf, Part I: The Barents Sea Region: Norwegian Petroleum Directorate Bulletin 6.

Grechka, V., and A. Pech, 2006, Quartic reflection moveout in a weakly anisotropic dipping layer: Geophysics, 71, no. 1, D1-D13, doi: 10 $.1190 / 1.2159047$

Hallam, A., 2001, A review of the broad pattern of Jurassic sea-level changes and their possible causes in the light of current knowledge: Palaeogeography, Palaeoclimatology, Palaeoecology, 167, 23-37, doi: 10.1016/ S0031-0182(00)00229-7.

Harms, J., P. Tackenberg, E. Pickles, and R. Pollock, 1981, The Brae oilfield area, in L. V. Illing, and G. D. Hobson, eds., Petroleum geology of the continental shelf of north-west Europe: Heyden, 352-357.

Haq, B. U., J. Hardenbol, and P. R. Vail, 1987, Chronology of fluctuating sea levels since the Triassic: Science, 235, 1156-1167, doi: 10.1126/science 235.4793.1156

Henriksen, E., H. M. Bjørnseth, T. K. Hals, T. Heide, T. Kiryukhina, O. S. Kløvjan, G. B. Larssen, A. E. Ryseth, K. Rønning, K. Sollid, and A. Stoupakova, 2011, Uplift and erosion of the greater Barents Sea: Impact on prospectivity and petroleum systems, in A. M. Spencer, A. F. Embry, D. L. Gautier, A. V. Stoupakova, and K. Sørensen, eds., Arctic petroleum geol- 
ogy: Geological Society of London, Memoirs 35, 271-281, doi: 10.1144/ M35.17.

Hornby, B. E., 1998, Experimental laboratory determination of the dynamic elastic properties of wet, drained shales: Journal of Geophysical Research: Solid Earth, 103, 29945-29964, doi: 10.1029/97JB02380.

Jakobsen, M., and T. A. Johansen, 2000, Anisotropic approximations for mudrocks: A seismic laboratory study: Geophysics, 65, 1711-1725, doi: $10.1190 / 1.1444856$.

Johnston, D. H., 1987, Physical properties of shale at temperature and pressure: Geophysics, 52, 1391-1401, doi: 10.1190/1.1442251.

Johnston, J. E., and N. I. Christensen, 1995, Seismic anisotropy of shales: Journal of Geophysical Research: Solid Earth, 100, 5991-6003, doi: 10 $.1029 / 95 J B 00031$.

Jones, L. E. A., and H. F. Wang, 1981, Ultrasonic velocities in Cretaceous shales from the Williston basin: Geophysics, 46, 288-297, doi: 10.1190/1 .1441199 .

Jones, T. D., and A. Nur, 1984, The nature of seismic reflections from deep crustal fault zones: Journal of Geophysical Research: Solid Earth, 89, 3153-3171, doi: 10.1029/JB089iB05p03153.

Klemme, H. and G. F. Ulmishek, 1991, Effective petroleum source rocks of the world: Stratigraphic distribution and controlling depositional factors: AAPG Bulletin, 75, 1809-1851.

Mavko, G., T. Mukerji, and J. Dvorkin, 2009, Rock physics handbook: Tools for seismic analysis of porous media: Cambridge University press.

Meadows, M. A., and W. L. Abriel, 1994, 3-D poststack phase-shift migration in transversely isotropic media: 64th Annual International Meeting, SEG, Expanded Abstracts, 1205-1208.

Mondol, N. H., 2009, Porosity and permeability development in mechanically compacted silt-kaolinite mixtures: 79th Annual International Meeting, SEG, Expanded Abstracts, 2139-2143.

Mondol, N. H., 2012, Velocity anisotropy in experimentally compacted clay-silt and clay-clay mixtures: 82nd Annual International Meeting, SEG, Expanded Abstracts, doi: 10.1190/segam2012-0125.1.

Mondol, N. H., K. Bjørlykke, and J. Jahren, 2008, Experimental compaction of clays: Relationship between permeability and petrophysical properties in mudstones: Petroleum Geoscience, 14, 319-337, doi: 10.1144/ 1354-079308-773.

Mondol, N. H., K. Bjørlykke, J. Jahren, and K. Høeg, 2007, Experimental mechanical compaction of clay mineral aggregates - Changes in physical properties of mudstones during burial: Marine and Petroleum Geology, 24, 289-311, doi: 10.1016/j.marpetgeo.2007.03.006.

Mondol, N. H., L. Grande, E. Aker, T. Berre, T. Ørbech, K. Duffaut, J. Jahren, and K. Bjørlykke, 2010, Velocity anisotropy of a shallow mudstone core: 72nd Annual International Conference and Exhibition, EAGE, Extended Abstracts, doi: 10.3997/2214-4609.20145372.

NPD, 2015, Norwegian Petroleum Directorate FactPages, http://www.npd. no/engelsk/cwi/pbl/en/index.htm, accessed 12 January 2017.

Ohm, S. E., D. A. Karlsen, and T. Austin, 2008, Geochemically driven exploration models in uplifted areas: Examples from the Norwegian Barents Sea: AAPG Bulletin, 92, 1191-1223, doi: 10.1306/06180808028.

Pech, A., and I. Tsvankin, 2004, Quartic moveout coefficient for a dipping azimuthally anisotropic layer: Geophysics, 69, 699-707, doi: 10.1190/1 .1759456 .

Pech, A., I. Tsvankin, and V. Grechka, 2003, Quartic moveout coefficient: 3D description and application to tilted TI media: Geophysics, 68, 16001610, doi: $10.1190 / 1.1620634$.

Pervukhina, M., and P. N. J. Rasolofosaon, 2015, Burial/compaction and seismic anisotropy in shaly formations: 77th Annual International Conference and Exhibition, EAGE, Extended Abstracts, doi: 10.3997/2214-4609 .201413227 .
Poppe, L., V. Paskevich, J. Hathaway, and D. Blackwood, 2001, A laboratory manual for X-ray powder diffraction: U.S. Geological Survey Open-File Report 1, 1-88.

Rai, C. S., and K. E. Hanson, 1988, Shear-wave velocity anisotropy in sedimentary rocks: A laboratory study: Geophysics, 53, 800-806, doi: 10 $.1190 / 1.1442515$.

Sarout, J., C. Delle Piane, D. Nadri, L. Esteban, and D. N. Dewhurst, 2015, A robust experimental determination of Thomsen's $\delta$ parameter: Geophysics, 80, no. 1, A19-A24, doi: 10.1190/geo2014-0391.1.

Sarout, J., L. Esteban, C. Delle Piane, B. Maney, and D. N. Dewhurst, 2014 Elastic anisotropy of Opalinus clay under variable saturation and triaxial stress: Geophysical Journal International, 198, 1662-1682, doi: 10.1093/ gji/ggu231.

Sarout, J., and Y. Guéguen, 2008a, Anisotropy of elastic wave velocities in deformed shales: Part $1-$ Experimental results: Geophysics, 73, no. 5, D75-D89, doi: 10.1190/1.2952744.

Sarout, J., and Y. Guéguen, 2008b, Anisotropy of elastic wave velocities in deformed shales: Part 2 - Modeling results: Geophysics, 73, no. 5, D91-D103, doi: 10.1190/1.2952745.

Sayers, C. M., 1999, Stress-dependent seismic anisotropy of shales: Geophysics, 64, 93-98, doi: 10.1190/1.1444535.

Skurtveit, E., L. Grande, O. Y. Ogebule, R. H. Gabrielsen, J. I. Faleide, N. H Mondol, R. Maurer, and P. Horsrud, 2015, Mechanical testing and sealing capacity of the Upper Jurassic Draupne Formation, North Sea: 49th US Rock Mechanics/Geomechanics Symposium, ARMA, Expanded Abstracts.

Sondergeld, C. H., and C. S. Rai, 2011, Elastic anisotropy of shales: The Leading Edge, 30, 324-331, doi: 10.1190/1.3567264.

Sondergeld, C. H., C. S. Rai, R. W. Margesson, and K. J. Whidden, 2000, Ultrasonic measurement of anisotropy on the Kimmeridge Shale: 70th Annual International Meeting, SEG, Expanded Abstracts, 18581861.

Thomsen, L., 1986, Weak elastic anisotropy: Geophysics, 51, 1954-1966, doi: 10.1190/1.1442051.

Tissot, B. P., and D. H. Welte, 1978, Petroleum formation and occurrence: A new approach to oil and gas exploration: Springer-Verlag.

Underhill, J. R., and M. A. Partington, 1993, Jurassic thermal doming and deflation in the North Sea: Implications of the sequence stratigraphic evidence, in J. R. Parker, ed., Proceedings of the Fourth Conference Petroleum Geology of Northwest Europe: Geological Society, 337-345.

Vanorio, T., T. Mukerji, and G. Mavko, 2008, Emerging methodologies to characterize the rock physics properties of organic-rich shales: The Leading Edge, 27, 780-787, doi: 10.1190/1.2944163.

Vernik, L., and C. Landis, 1996, Elastic anisotropy of source rocks: Implications for hydrocarbon generation and primary migration: AAPG Bulletin, 80, 531-544.

Vernik, L., and X. Liu, 1997, Velocity anisotropy in shales: A petrophysical study: Geophysics, 62, 521-532, doi: 10.1190/1.1444162.

Vernik, L., and A. Nur, 1992, Ultrasonic velocity and anisotropy of hydrocarbon source rocks: Geophysics, 57, 727-735, doi: 10.1190/1 .1443286 .

Vollset, J., and A. G. Doré, 1984, A revised Triassic and Jurassic lithostratigraphic nomenclature for the Norwegian North Sea: NPD-Bulletin 3.

Wang, Z., 2002, Seismic anisotropy in sedimentary rocks, Part 2: Laboratory data: Geophysics, 67, 1423-1440, doi: 10.1190/1.1512743.

Wissa, A., J. Christian, E. Davis, and S. Heiberg, 1971, Consolidation testing at constant rate of strain: ASCE Journal of Foil Mechanics and Foundations Division, 97, 1393-1413.

Wright, J., 1987, The effects of transverse isotropy on reflection amplitude versus offset: Geophysics, 52, 564-567, doi: 10.1190/1.1442325. 